\title{
Surface modification methods of ceramic filler in ceramic-carbon fibre composites for bioengineering applications - A systematic review
}

https://doi.org/10.1515/rams-2020-0024

Received Nov 01, 2019; accepted Apr 23, 2020

\begin{abstract}
The present review paper focuses on the current state of the art of the alumina-silicate ceramics and surface modifications of ceramics dedicated as fillers in composites with carbon fiber. The use of aluminum-silicates in the form of a cenosphere due to their outstanding properties, i.e., low density, high hardness, and total chemical inertness seem to be promising in biomaterial engineering applications. First of all, the possibilities of the composites application in orthopedic and prosthetic implantology. The following section discusses problems with the use of aluminum silicate ceramics and their processing. Subsequently, in the paragraphs to follow, the possibilities of modifying the surface with chemical methods are discussed, among others oxidation, chemical methods like ionic liquids etching, silanization, and physical processes i.e., thermal treatment. In the summary, the directions of development of ceramic-carbon fiber composites and the primary deficiencies of these composites on which to focus on and solve are discussed.
\end{abstract}

Keywords: bioceramics, carbon fibre, composites, implants, orthopaedics, prosthetic dentistry

\section{Introduction}

The elongation of the average human life observed since the 1970s, and the aging of highly developed societies

\footnotetext{
*Corresponding Author: Damian S. Nakonieczny: Department of Biomaterials and Medical Devices Engineering, Faculty of Biomedical Engineering, Silesian University of Technology, Roosevelt 40 st., Zabrze, 41-800 Oberschlesien, Poland; Email: damian.nakonieczny@polsl.pl; Tel.: +48 0791515766

Magdalena Antonowicz, Zbigniew Paszenda: Department of Biomaterials and Medical Devices Engineering, Faculty of Biomedical Engineering, Silesian University of Technology, Roosevelt 40 st., Zabrze, 41-800 Oberschlesien, Poland
}

which is especially noticeable especially in Western Europe, and the observed increase in interest in extreme sports with a high degree of injury rate, forced the introduction of new procedures and implants in the field of orthopedics, reconstructive surgery and prosthetic dentistry. The development in this area is associated with the introduction to the clinical practice of metal implants made of LVM 316 stainless steel and titanium and its alloys, in particular [1, 2]. Application of the so-called plates for osteosynthesis, screws, bone screws and rods have revolutionized the treatment of complicated fractures, the fusion of bone fragments and articular alloplasty thanks to which mainly elderly people's locomotor opportunities and relatively comfortable living conditions were restored.

With the use of metal implants, the issues of corrosion resistance, the accumulation of metallic ions in the human body, and the impact on homeostasis are inextricably connected. These phenomena have so far found no solution that would entirely eliminate the negative metal implant influence on the human body environment. The negative effect is primarily demonstrated by the accumulation of metallic ions in detoxification organs, metallosis and in extreme cases, cancer lesions. A recognized way to counteract these negative phenomena is to modify the surface of metal biomaterials. The modification processes can be carried out by laser, plasma, ion implantation, hydroxyapatite deposition, and the use of CVD/PVD processes, modified by chemical techniques i.e., with the sol-gel method films deposition. Another recognized method of increasing the biocompatibility of alloy coatings is the use of bioactive surfaces [3-5]. The most frequently used method for modifying the surface of metal biomaterials is the use of electrochemical techniques - mainly anodic oxidation in individual bathing mixtures [6].

The use of other biomaterials, preferably those similar to the human bone mechanical characteristics and lacking inflammatory and allergic reactions to which metal implants contribute is an alternative way to solve problems related to the use of metal implants [7]. Polymerceramic composites provide one of the most perspective

๑ Open Access. (C 2020 D. S. Nakonieczny et al., published by De Gruyter. 
solutions. They combine the best features of ceramics: low abrasiveness, no negative impact on the human body and shape-forming precision, with the features of polymers: low weight, the ability to shape mechanical characteristics in a wide range $[8,9]$. Particular attention is focused on polymers of PEEK, CF, and PA groups [10, 11]. The research for new materials characterized by better anti-corrosive properties and the lack of a negative impact on the body environment is one of the most promising development directions in the field of biomaterial engineering with proven application potential, especially in the field of orthopedics and dental prosthetics.

In this article, the authors present their study resulting from previous experiences with ceramics i.e. $\mathrm{ZrO}_{2}$ for the prospects of using carbon fiber composites and aluminumsilicates in the form of the so-called cenospheres [12-14]. The review discusses, in turn, the properties and origin of cenospheres, the possibilities of obtaining composites with carbon fiber, surface modification methods of cenospheres that improve adhesion to polymer resin and finally, application perspectives of the new material in orthopedics and prosthetic dentistry.

\section{Cenospheres general information}

In this article, particular attention is drawn to aluminiumsilicates that come from the combustion of stone coal. Aluminosilicate microspheres, commonly referred to as cenospheres are light ceramic spheres with sub-micrometer dimensions which interior is slightly under pressure. They are characteristic for variable density in the range 350-850 $\mathrm{kg} / \mathrm{m}^{3}$, a very low thermal conductivity coefficient $(\lambda<0.1$ $\mathrm{Wm}^{-1} \mathrm{~K}^{-1}$ ), and complete chemical inertness. The selected properties are summarized in the table (Table 1). Microspheres do not show any harmful effects on animal organisms $[15,16]$. Cenospheres are a by-product produced during stone coal combustion, and their chemical composition and percentage in ash are strongly dependent on the type of coal, the contaminant content i.e., sulfur and nitrogen oxides, mineral content and the degree of exploitation of the furnace and combustion temperature [15]. The structure of the cenospheres is presented in the diagram (Figure 1). Given the application possibilities and potential applications, microspheres are the most valuable fraction of fly ash from stone coal combustion, it is estimated that their content in the dry post-process weight is about 0.3$1.5 \%$ weight, which, taking into account the global production of fly ash at the level of about 750 million, gives approx. 2.25-11.25 million tons per year [15]. The main directions of development of the emerging microspheres are, among others, petroleum industry, energy-saving construction, light precast concrete products, heat-resistant coatings, and drug-carriers of active substances $[15,16]$. Due to its spherical shape, the discussed ceramic material shows excellent surface wettability, thanks to which it can be used, among other things as an economical filler for biomedicalgrade composites; it additionally allows the reduction of the proportion necessary to obtain resin adhesion and positively affects the improvement of mechanical properties, and the reduction of composite mass $[15,17,18]$.

The chemical composition of cenospheres does not differ significantly from the composition of fly ash after coal combustion $[15,19,20]$. Based on the available data, it can be stated that even more than $90 \mathrm{wt} . \%$ of the cenospheres utilize $\mathrm{SiO}_{2}$ and $\mathrm{Al}_{2} \mathrm{O}_{3}$ in different compositions. The chemical composition diagram analysis leads to the conclusion that the cenospheres the fly ash belongs to,

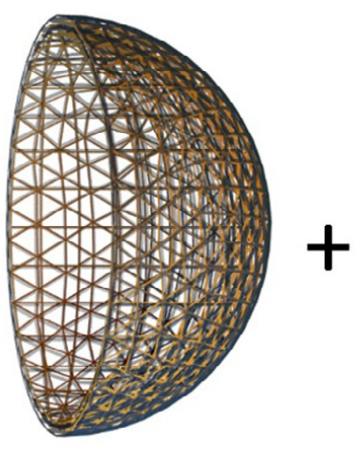

Crystalline phases

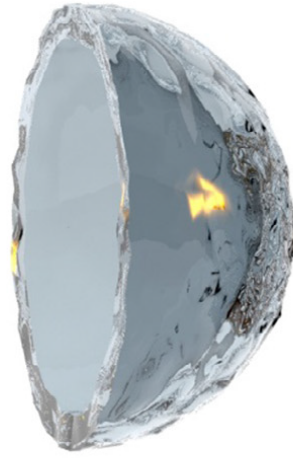

Amorphous glass phases

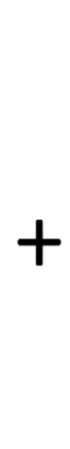

Other crystalline phases forms at surface

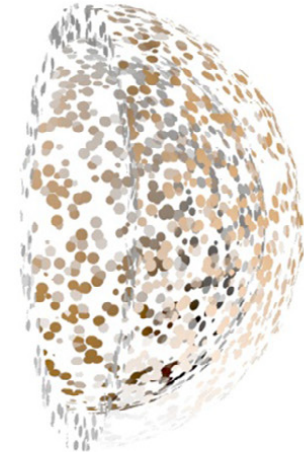

(1)

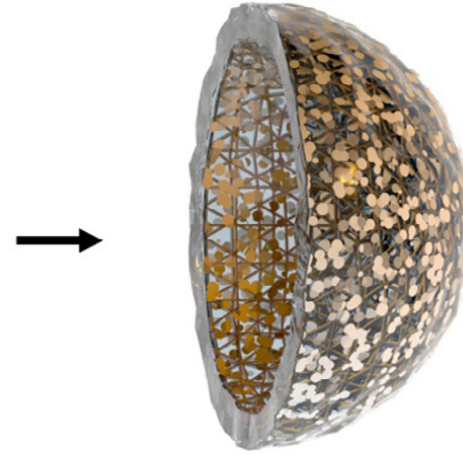

Cenosphere phase composition structure

Principal phases of cenospheres

Figure 1: Schematic phase composition and structure of a cenosphere [15] 
Table 1: Selected properties of the alumina-silcatecenospheres $[15,26]$

\begin{tabular}{|c|c|c|c|}
\hline \multicolumn{2}{|c|}{ Physical Properties } & \multicolumn{2}{|c|}{ Chemical Composition, wt\% } \\
\hline Real particle density, $\mathrm{kg} \times \mathrm{m}^{-3}$ & $750-800$ & $\mathrm{Al}_{2} \mathrm{O}_{3}$ & $16.70-29.30$ \\
\hline Bulk density, $\mathbf{k g} \times \mathrm{m}^{-3}$ & $400-450$ & $\mathrm{CaO}$ & $1.06-2.50$ \\
\hline Hardness (Mohs), MOH & $5-6$ & $\mathrm{SiO}_{2}$ & $58.50-73.10$ \\
\hline Compressive Strength, $\mathbf{k g} \times \mathrm{m}^{-3}$ & $180-280$ & $\mathrm{SO}_{4}$ & c.a. 0.42 \\
\hline Packing Factor, $\%$ & $60-65$ & $\mathrm{SO}_{3}$ & $0.19-0.36$ \\
\hline Melting Point, ${ }^{\circ} \mathrm{C}$ & $1200-1300$ & $\mathrm{Na}_{2} \mathrm{O}$ & $0.60-2.42$ \\
\hline \multirow[t]{2}{*}{ pH in Water, - } & $6-7$ & $\mathrm{~K}_{2} \mathrm{O}$ & $1.98-3.94$ \\
\hline & & $\mathrm{TiO}_{2}$ & $0.35-1.79$ \\
\hline \multirow[t]{2}{*}{ Moisture, \% } & $0.5 \max$. & MgO & $0.32-2.30$ \\
\hline & & $\mathrm{Fe}_{2} \mathrm{O}_{3}$ & $1.96-21.04$ \\
\hline
\end{tabular}

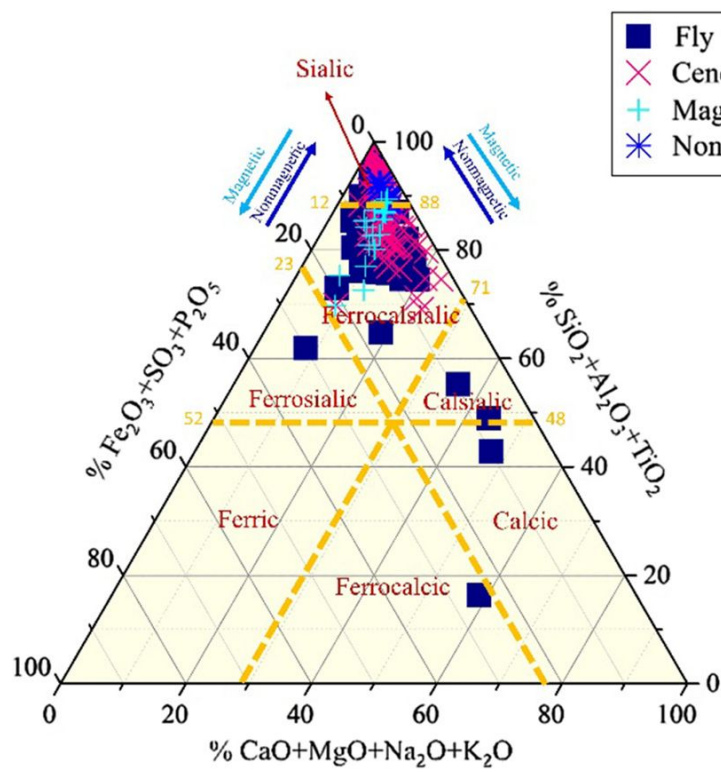

a

Figure 2: The ternary diagram of the chemical composition of selected fly ashes and cenospheres (Ranjbar and Kenzel); a) full diagram, b) cenospheres forming area: sialic and ferricalcsialic groups [15]

comprise six groups: calic, calsilic, ferrosialic, ferrocalsialic, ferrocalcic and sialic (Figure 2) [15]. The critical structural component determining the formation of the cenospheres is $\mathrm{TiO}_{2}$. Its presence positively affects the creation of spheres' shape. Based on the analysis of the chemical composition and combustion data, it was found that despite its small share $(0.35-1.79$ wt.\% $), \mathrm{TiO}_{2}$ is indispensable in cenosphere formation [15]. This phenomenon is probably due to the high surface energy of $\mathrm{TiO}_{2}$, which, in combination with the low viscosity of the stone coal slag during combustion, leads to the formation of spheres [15, 22, 23].
The phase composition, besides the chemical composition, is the crucial factorthat makes cenospheres an interesting material with potential applications in carbon fiber composites. It can be assumed that such microspheres consist of a crystalline continuous skeleton and an amorphous shell that forms a smooth sphere shape [22, 23]. Due to the presence of iron and its crystalline compounds, cenospheres are divided into two major groups: magnetic and non-magnetic particles [15, 24-26]. Grains built mainly from $\mathrm{SiO}_{2}$ in their composition are non-magnetic ones, while cenospheres form the ferrosialic group that exhibits magnetic interactions $[15,23]$. One can generally conclude that the decrease in silicon in the content of minerals, de- 
Table 2: Carbon fiber basic properties and comparison of carbon fiber, glass fiber, and Kevlar fiber, and carbon steel [30]

\begin{tabular}{ccccc}
\hline Property & $\begin{array}{c}\text { Carbon fiber } \\
\text { (Toray T300) }\end{array}$ & $\begin{array}{c}\text { Glass fiber } \\
\text { (Glass fiber S-2) }\end{array}$ & $\begin{array}{c}\text { Kevlar Fiber } \\
\text { (49) }\end{array}$ & Carbon steel \\
\hline Density $\left(\mathrm{g} / \mathrm{cm}^{3}\right.$ ) & 1.76 & 2.46 & 1.45 & 7.85 \\
Tensile modulus $(\mathrm{GPa})$ & 230 & 86.9 & 112 & $190-210$ \\
Specific tensile modulus $\left(\mathrm{GPa} \cdot \mathrm{cm}^{3} / \mathrm{g}\right)$ & 131 & 35.3 & 77.2 & $24.2-26.8$ \\
Tensile strength $(\mathrm{GPa})$ & 3.53 & 4.89 & 3.00 & $0.276-1.882$ \\
Specific tensile strength $\left(\mathrm{GPa} \cdot \mathrm{cm}^{3} / \mathrm{g}\right)$ & 2.010 & 1.990 & 2.070 & $0.035-0.24$ \\
Tensile strain $(\mathrm{ductility)}$ & $1.5 \%$ & $5.7 \%$ & $2.4 \%$ & $10-32 \%$ \\
Compressive strength $(\mathrm{GPa})$ & $0.87^{\star}$ & 1.60 & - & - \\
${ }^{\star \star} \mathrm{CTE}\left(\right.$ axial, $\left.10^{-6} / \mathrm{K}\right)$ & -0.41 & 2.9 & -6 & $11.0-16.6$ \\
\hline
\end{tabular}

*calculated value [30], ${ }^{\star \star} \mathrm{CTE}-$ cofficient of thermal expansion

Table 3: Carbon fiber basic properties and comparison of carbon fiber, glass fiber and Kevlar fiber and carbon steel [39]

\begin{tabular}{cccccc}
\hline Fiber type & ${ }^{*} \mathbf{Z}_{\text {FWHM }}(\mathcal{P})$ & ${ }^{*} \boldsymbol{E}(\mathbf{G P a})$ & ${ }^{a}{ }^{\boldsymbol{i}} \boldsymbol{i}(\mathbf{G P a})$ & ${ }^{b} \boldsymbol{\sigma}_{\boldsymbol{c}}^{j}(\mathbf{G P a})$ & ${ }^{c} \boldsymbol{G}_{\mathbf{1 2}}(\mathbf{G P a})$ \\
\hline IM6 & 33.7 & 308 & - & - & $42.1 ; 10.1 \pm 0.8$ \\
IM7 & 30.2 & 276 & - & - & $29.5 \sim 16.2 \pm 2.5$ \\
T300 & 35.0 & 230 & $1.4 ; 1.8$ & 1.0 & $29.8 \sim 14$ \\
T1000 & 31.5 & 294 & 2.8 & 2.2 & 35.1 \\
M40J & 21.4 & 377 & 1.8 & 1.0 & $26.7 \sim 20$ \\
M60J & 9.9 & 588 & 1.0 & 0.5 & $13.5 \sim 15$ \\
P55 & 14.1 & 379 & 0.8 & - & 11.9 \\
P100 & 5.6 & 724 & 0.8 & - & 7.6 \\
P120 & 5.6 & 827 & - & - & 12.4 \\
\hline
\end{tabular}

* Full-width at half maximum (ZFWHM) of the azimuthal X-ray diffraction pattern,

$\star \star$ Young modulus,

$\star a$ characteristic strength [39]

$\star b$ characteristic strength [39]

$\star c$ Carbon fiber longitudinal shear modulus

creases the percentage share in the ashes of cenospheres with smooth shells or spherical alumina silicates. For readers who want to deepen their knowledge in the field of receiving of cenospheres and their chemical and physical properties, the current state of knowledge may be found in the review paper of N. Ranjabar, C. Kuenzel [15].

\section{Carbon fibers characteristics}

Carbon fibers appear an interesting alternative to engineering materials widely used in implantology, i.e., stainless steels and titanium and its alloys [27, 28]. The main properties that make the application of carbon fibers attractive are the low thermal conductivity of approx. $6 \mathrm{WmK}^{-1}$, almost no thermal linear expansion, and easy shape formation, which allows obtaining even very complicated shapes, mainly dependent on the quality of the matrix, and susceptibility to corrosion and diffusion of ions in the environment exposed to liquids and elevated temperature [29].

High values of mechanical properties can be additionally shaped in a wide range, among others tensile strength $252-1600 \mathrm{Nmm}^{-2}$, which are mainly dependent on the type of fiber arrangement and their adhesion to epoxy resin [29]. The main drawbacks of carbon fiber are low strength to UV radiation and relatively low resistance to temperatures above $200^{\circ} \mathrm{C}[29,30]$. In the first case, it is possible to achieve an increase in strength with the lacquer layers addition. In the second case, the thermal resistance is increased by the use of other resins, e.g., phenolic resins, thanks to which short-term resistance of approx. $500^{\circ} \mathrm{C}$ can be obtained [30]. Selected properties have been collected in the table (Table 2). In the next table, a short comparison between typical PAN (polyacrylonitrile)-based carbon fibers is shown (Table 3 ). 


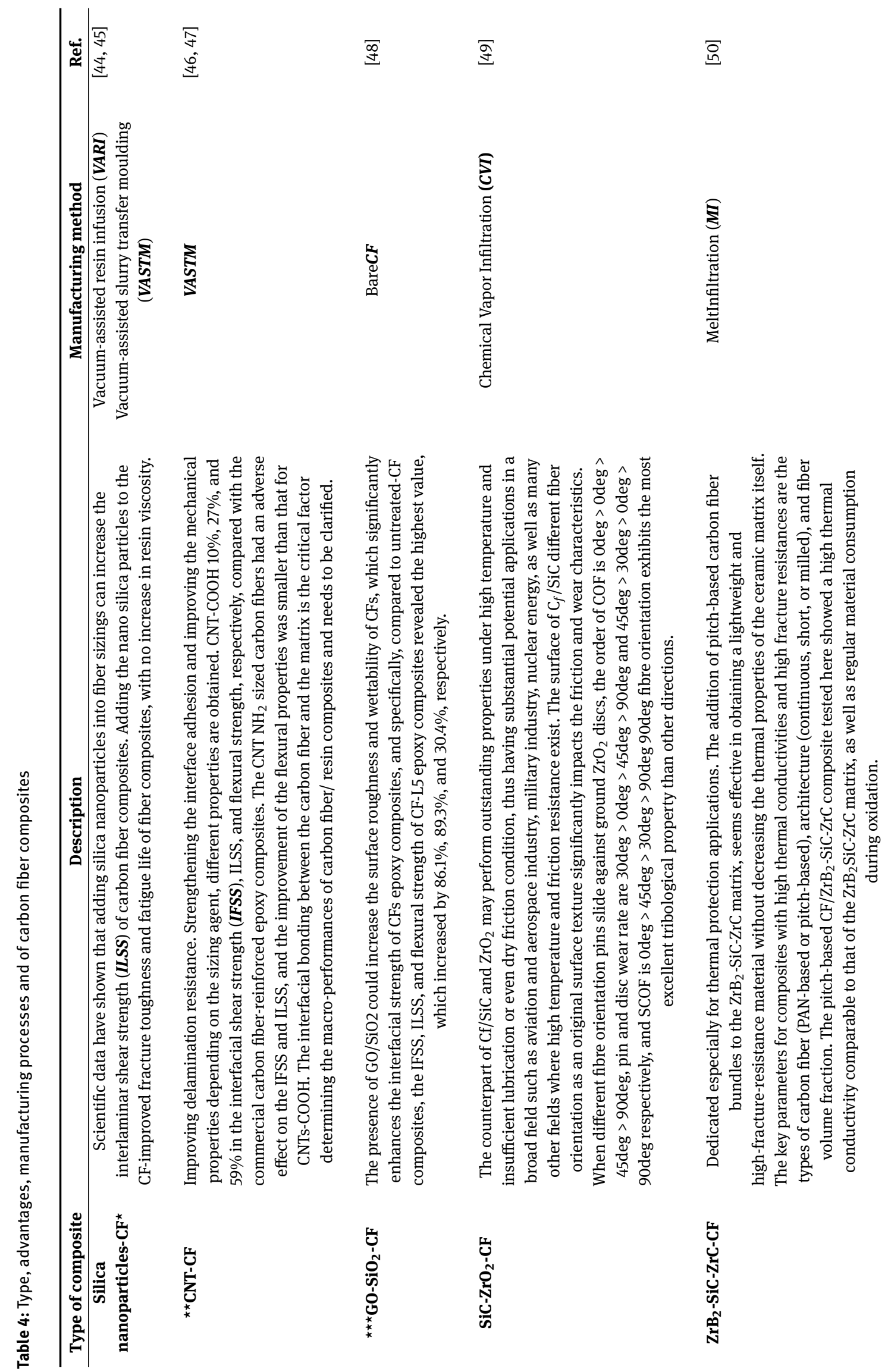




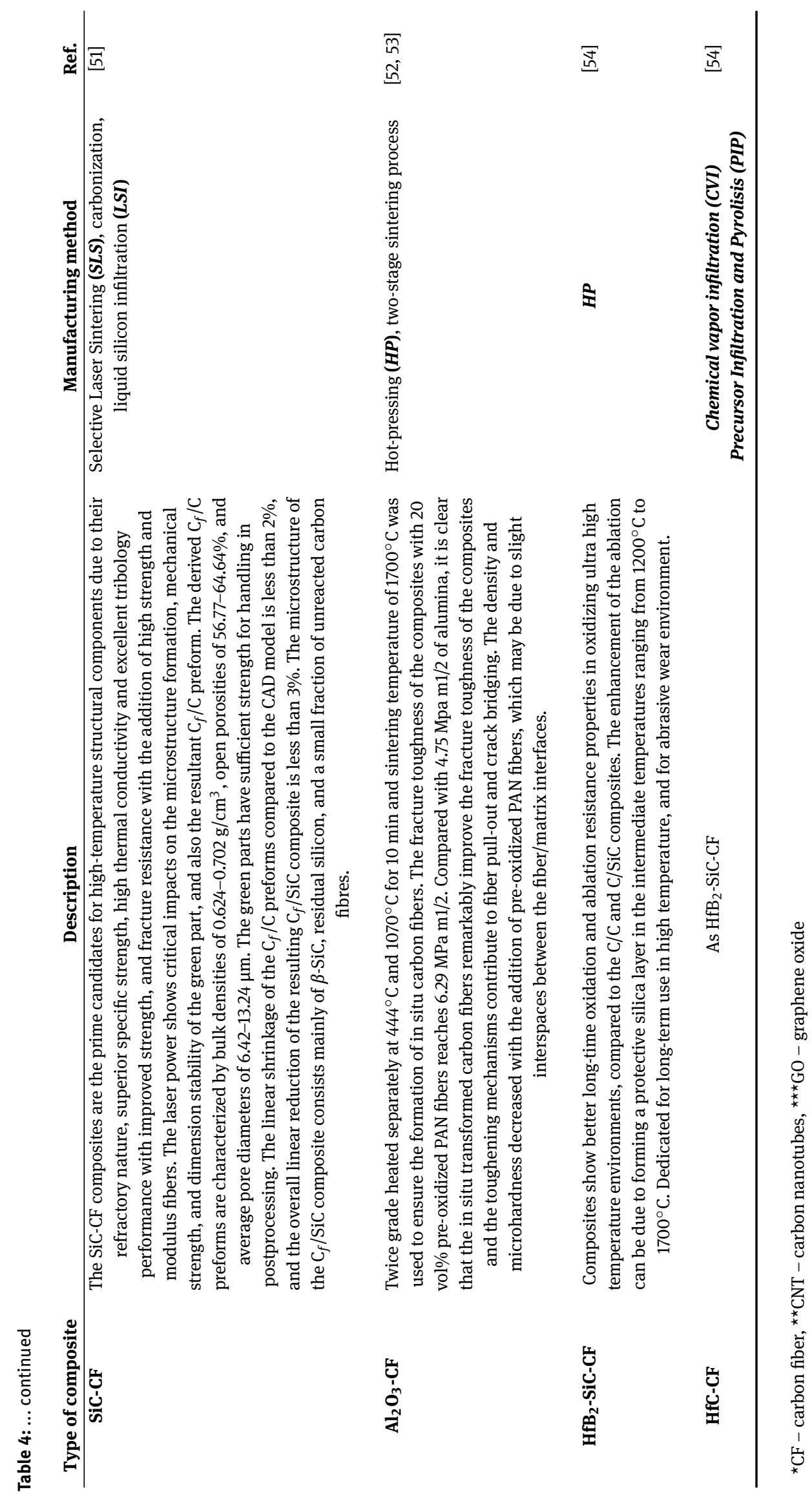


The main problems associated with the application of carbon fibers in biomedical applications are related to insufficient adhesion of the resin to the carbon braid. The issue basically concerns obtaining a sufficiently large development of the surface without adversely affecting the mechanical properties and susceptibility to degradation in the environment of body fluids [31, 32].

Based on the state of the art and our own experience in surface engineering and biomaterial engineering, carbon fiber modification includes among others oxidation, surface activation in supercritical conditions, surface modification with organometallic compounds, and introduction of small grain size ceramics to the resin matrix [33-38].

Analyzing all mentioned above modification methods and combining their characteristics, the most promising approach seems to be the introduction of ceramics grains into carbon fiber reinforcement and obtaining ceramicpolymer composites with intermediate properties between the base materials. This seems particularly justified when considering the use of the material in implantology [39]. This issue is quite sophisticated. Biomedical applications force the use of the material with high mechanical properties which however are as close as possible to the mechanical properties of human bones or other tissues. In addition, such material must not be toxic to the human body (cytotoxicity) and should provide obtaining complicated shapes in a way that is not very cost-intensive and precise. The last issue is particularly important since it is necessary to remember each patient's individual anthropomotoric features which are highly variable, regardless of whether the motion or stomatognathic system is considered or facial-skull structure, temporomandibular joint or the entire system functions [31, 32].

The most important reason for the composite materials made of ceramics and polymers, carbon fibers, in particular, to be used in biomedical engineering and other demanding applications is that such materials combine the best features of ceramics and polymers with any of their drawbacks.

Obtaining a composite with the addition of carbon fibers allows to improve the fracture toughness of ceramics, the most promising approach is the introduction of toughening hases, such as particles, whiskers, and fibers. Among different types of toughening phases, the fiber with a large aspect ratio is a promising reinforcement due to its versatile toughening mechanisms, such as fiber pullout, fiber-matrix interface debonding, crack deflection and fiber bridging [38, 39]. Furthermore, Sha et al. inform that despite the influence on the improvement of mechanical properties, the addition of carbon fibers to $\mathrm{Zr}$ ceramics is crucial for reducing the sintering temperature [41].
However, the key to obtaining expensive composites is to achieve a lasting connection between ceramics and carbon materials. Cho et al. indicate that the interfacial characteristics are one of the most critical parameters that determine the bulk composite properties [40]. Many types of research have been conducted to address this issue, including chemical oxidation, high-energy beam irradiation, surface treatment by a rare-earth. Most recently, the introduction of carbon nanomaterials such as CNTs and graphenemodified resins open a new possibility for the tailoring of interfacial characteristics [41-43].

Taking into account the mentioned relationships, the table below presents the information on composites composed of carbon fibers and, among others, ceramics that can be used in biomaterial engineering, and presents a short point of view on the state of the art issues concerning carbon fiber composites (Table 4).

\section{Ceramic surface modification}

Modification of the ceramic surface and the bioceramics count is a crucial key factor in considering the attractiveness of bioceramic implants or other medical devices. Zirconium oxide in dental prosthetics is an excellent example of bioceramic modification problems $[14,55]$. The zirconiabased materials is a biomaterial with the high chemical stability that avoids the release of toxic products to the surrounding tissues [56-58]. The Y-TZP provides stimulation of osteogenic cells at osseointegration, combined with unique mechanical characteristics such as high fracture toughness, fatigue resistance, high bending strength, high corrosion resistance, and radiopacity [56]. Unfortunately, based on clinical trials, it was noticed that zirconia-based surfaces had revealed a lower number of bacteria when compared to titanium implant surfaces regarding microbiological assays [56, 57]. Despite the favorable findings recorded for zirconia-based surfaces, the long-term clinical results are still lacking, and some controversies towards zirconia osseointegration are still discussed. Therefore, constant digesting the scientific work on the explanation of the impact of the implant surface development on the survival of implants in the human body, and the selection of appropriate methods of surface modification that improves the survival of the implant in the human body can be noted.

The preparation of ceramic polymer composites is another issue related to the modification of the ceramic surfaces. Namely, it is about obtaining a maximum development of the ceramic specific surface area, which enables 
obtaining permanent adhesion with polymer resins and obtaining a mechanically stable material $[58,59]$. There are many ways to create a sufficiently large surface development on the ceramic surface: oxidation, application of specific functional groups, silanization, thermal capsule in a variable gas atmosphere, physical methods, i.e., melt infiltration and chemical etching process. Koch, Horn, and Buchmeiser team presented good work on carbon fibre-SiC composites and adhesion of ceramics to polymer, which reflect the essence of problems in this type of composites [60]. The composite microstructure is strongly related to the mechanical properties, and especially important for the damage tolerant failure behavior. Quasi-ductile fracture behavior is attributed to the occurrence of energydissipative mechanisms, like fiber pull-out, fiber bridging, and crack deflection. Therefore, a tailored fiber-matrix adhesion (FMA) in the carbon fiber reinforced polymer (CFRP) and C/C state is required [60]. In the CFRP preform, cracks are initiated by the volume shrinkage of the polymer matrix due to crosslinking at curing, as well as by the thermal contraction of the matrix at cooling after curing. The resulting crack pattern facilitates the infiltration of the porous $\mathrm{C} /$ Cpreform with liquid silicon by capillary forces [60].

The following paragraphs present chosen methods of ceramic surface modification and methods of their implementation.

\subsection{Chemical Etching}

Chemical etching is one of the better known and the simplest methods of biomaterial surface modification, including bioceramics. Depending on variables such as chemical composition, temperature, reagent concentrations in etching baths, $\mathrm{pH}$, or the process in the form of electrochemical etching, a wide range of ceramic-modification possibilities are obtained [61, 62]. Given the type of a reagent used, di- gestion is divided into etching in acids and bases. The most significant amount of literature data on chemical digestion concerns the preparation of the $\mathrm{ZrO}_{2}$ surface in a way that enables permanent bonding to dental hard tissues or composite materials [63]. An important aspect required for the success of $\mathrm{ZrO}_{2}$ ceramics is the establishment of proper adhesion between substrate and adherent [63, 64]. In this sense, the gold-standard protocol for resin bonding to glass-ceramics is the etching with hydrofluoric acid followed by the application of a silane coupling agent (chemical and micro-mechanical bond) [63, 64]. Numerous variations in HF acid etching (time, concentration) have shown to change the surface micro-morphology of glass-ceramics (many surface defects) [63] and resin adhesion, the increase in HF acid concentration and etching time associated with an increase on the surface area available to adhesion with resin [63].

The above is just only one example of surface development through etching, which is the most representative nowadays. The time influence of the HF digestion on the surface of zirconium bioceramics has been shown in the figure (Figure 3). Table 5 below presents the most representative examples of the ceramic surface development by the etching process, the methods used and the characteristics, and the impact on the properties of bioceramics commonly used in prosthetic dentistry (Table 5).

\subsection{Silanization}

Silanization is one of the most common ways to modify ceramic surfaces, both solid and powder-like. Organofunctional alkoxysilanes, in particular, have been widely used to obtain high-density self-assembled monolayers (SAMs) on hydroxyl-terminated material surfaces, such as glass, silica, and metal oxides to modify or to modulate the properties or chemical functions of such surfaces [68]. Surface modification through silanization has generated in-
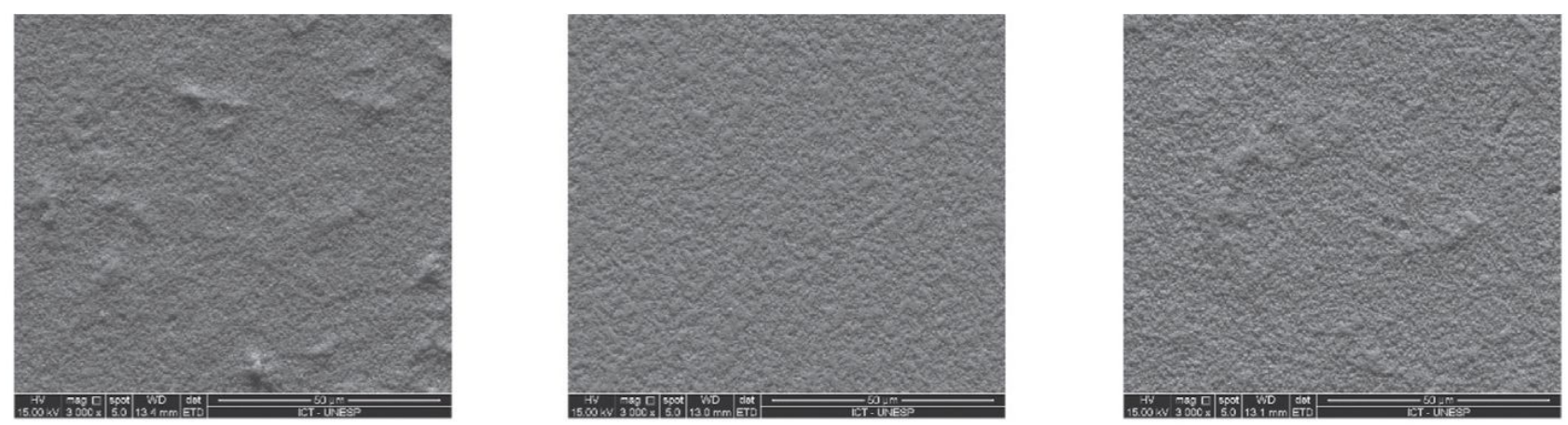

Figure 3: SEM-microphotograph of $5 \%$ etched $\mathrm{ZrO}_{2}$ samples: a) $30 \mathrm{~s}$ etching, b) $60 \mathrm{~s}$ etching, b) $90 \mathrm{~s}$ etching [64] 
Table 5: Chemical etching characteristics for various dental bioceramics

\begin{tabular}{|c|c|c|c|}
\hline $\begin{array}{l}\text { Etching } \\
\text { Agent }\end{array}$ & Ceramic Type & Influence & Ref. \\
\hline $0.5 \% \mathrm{HCl}$ & $\mathrm{Al}_{2} \mathrm{O}_{3}: \mathrm{ZnO}$ & spherical agglomerates structure, surface roughness $\mathrm{Ra}=29.998 \mathrm{~nm}$ & [65] \\
\hline $1.0 \% \mathrm{KOH}$ & $\mathrm{Al}_{2} \mathrm{O}_{3}: \mathrm{ZnO}$ & $\begin{array}{l}\text { nanorod like surface structure, better surface development than acid } \\
\text { etching, surface roughness } R a=53.04 \mathrm{~nm}\end{array}$ & [65] \\
\hline $4.8 \% \mathrm{HF}$ & $\begin{array}{c}\mathrm{KAISi}_{3} \mathrm{O}_{8}- \\
\mathrm{NaAlSi}_{3} \mathrm{O}_{8}- \\
\mathrm{CaAl}_{2} \mathrm{Si}_{2} \mathrm{O}_{8} \\
\text { (Feldspar) }\end{array}$ & $\begin{array}{l}\text { treatment with hydrofluoric acid resulted in increased surface roughness } \\
\text { with irregularities and pores on the treated surfaces, mean } \mathrm{Ra}=575.37 \mathrm{~nm}\end{array}$ & [66] \\
\hline $4.8 \% \mathrm{HF}$ & $\begin{array}{l}\mathrm{SiO}_{2}-\mathrm{Li}_{2} \mathrm{O}-\mathrm{K}_{2} \mathrm{O}- \\
\quad \mathrm{Al}_{2} \mathrm{O}_{3}\end{array}$ & $\begin{array}{l}\text { treatment with hydrofluoric acid resulted in increased surface roughness } \\
\text { with irregularities and pores on the treated surfaces, mean } R a=134.80 \mathrm{~nm}\end{array}$ & [66] \\
\hline $5 \%, 10 \% \mathrm{HF}$ & $\begin{array}{l}\mathrm{ZrO}_{2}-\mathrm{SiO}_{2}-\mathrm{Li}_{2} \mathrm{O}- \\
\quad \mathrm{K}_{2} \mathrm{O}-\mathrm{Al}_{2} \mathrm{O}_{3}\end{array}$ & $\begin{array}{c}\text { fatigue failure load improvement, the pretreatment of } 10 \% \mathrm{HF} \text { acid etch for } \\
60 \mathrm{~s} \text { up to } 90 \mathrm{~s} \text {, followed by the application of an adhesive that contains } \\
\text { silane and MDP ( } 10 \text {-Methacryloyloxydecyl dihydrogen phosphate) achieved } \\
\text { the best performance in prosthetic dentistry, etching with } 5 \% \mathrm{HF} \text { acid, } \\
\text { independent of time ( } 30 \mathrm{~s}, 60 \mathrm{~s} \text { or } 90 \mathrm{~s} \text { ), was shown not to change the } \\
\text { fatigue behavior of ceramics }\end{array}$ & [67] \\
\hline
\end{tabular}

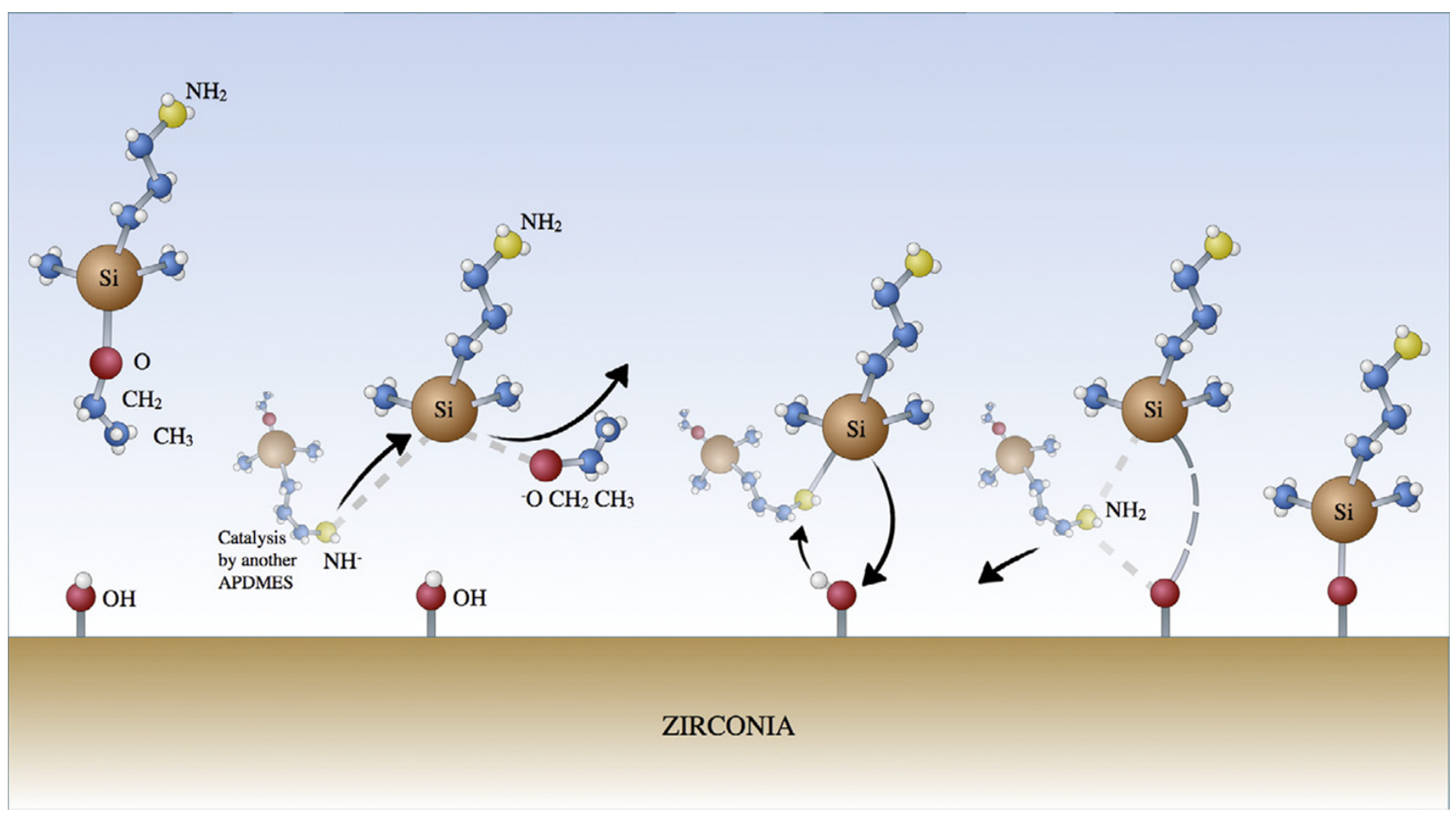

Figure 4: Schematic representation of silanization [74]

terest in terms of ceramic material surface modification to promote and improve adhesion to different resins, especially in prosthetic and general dentistry [68]. Silane compounds are commercially available, bearing amino, thiol, carboxyl, epoxide, etc. [68]. The silanization process is initialized by hydrolyzation of the alkoxysilane molecules. Depending on the number of water molecules present in the reaction system, the alkoxysilane molecules hydrolysis can occur in the liquid phase, resulting in self-aggregation in solution; it can also occur at the substrate surface, leading to the SAMs formation [68]. The generated silanols ( $\mathrm{Si}-$ $\mathrm{O}-\mathrm{H})$ then coordinate with the inorganic surface hydroxyls in a condensation reaction, forming siloxane bonds ( $\mathrm{Si}-\mathrm{O}-$ Si) to anchor the silane to the surface [68]. 
Table 6: Silanization process characteristics for various types of bioceramics

\begin{tabular}{|c|c|c|c|}
\hline Silanization Agent & Ceramic Type & Influence & Ref. \\
\hline $\begin{array}{c}1 \mathrm{H}, 1 \mathrm{H}, 2 \mathrm{H}, 2 \mathrm{H}- \\
\text { Perfluorooctyltriethoxysilane } \\
\text { (PTES) }\end{array}$ & $\begin{array}{c}\text { enamel } \\
\left(\mathrm{SiO}_{2}-\mathrm{B}_{2} \mathrm{O}_{3}-\mathrm{TiO}_{2}-\right. \\
\mathrm{Na}_{2} \mathrm{O}-\mathrm{K}_{2} \mathrm{O}-\mathrm{CaO}- \\
\mathrm{ZnO}-\mathrm{Al}_{2} \mathrm{O}_{3}-\mathrm{CoO}- \\
\left.\mathrm{ZrO}_{2} \mathrm{P}_{2} \mathrm{O}_{5}\right)\end{array}$ & $\begin{array}{l}\text { On modifications with the organic material called } \\
\text { perfluorooctyltriethoxysilane } \\
\text { (PTES), the enamel surfaces exhibited hydrophobic } \\
\text { properties with contact angle approaching } 120^{\circ} \text {. } \\
\text { Therefore, the enamel surfaces were modified to be } \\
\text { hydrophobic; The obtained hydrophobic properties were } \\
\text { thermally stable to a high temperature of } 400^{\circ} \mathrm{C}\end{array}$ & {$[71]$} \\
\hline $\begin{array}{c}3- \\
\text { Aminopropyltriethoxysilane } \\
\text { (APTES) }\end{array}$ & $\begin{array}{c}\text { glass-ceramic } \\
\left(99,4 \% \mathrm{SiO}_{2},\right. \\
\mathrm{Na}_{2} \mathrm{CO}_{3}, \mathrm{H}_{3} \mathrm{BO}_{3} \\
\left.\mathrm{CaCO}_{3}\right)\end{array}$ & $\begin{array}{c}\text { Surface modification with APTES shift the isoelectric point } \\
\text { of silica from in the case of the investigated silanized } \\
\text { glasses, a moderate shift of the isoelectric points to less } \\
\text { acidic values can be seen after silanization, together with } \\
\text { a shift of the surface charge at physiological pH to less } \\
\text { negative values }\end{array}$ & [72] \\
\hline $\begin{array}{l}\text { 3-Methacryloxypropyl } \\
\text { trimethoxysilane } \\
\text { (3-MPS) }\end{array}$ & $\begin{array}{c}\text { feldspathic } \\
\text { ceramic in glass } \\
\text { matrix } \\
\left(\mathrm{SiO}_{2}, \mathrm{Al}_{2} \mathrm{O}_{3}\right. \\
\left.\mathrm{Na}_{2} \mathrm{O}, \mathrm{K}_{2} \mathrm{O}\right)\end{array}$ & $\begin{array}{l}\text { The heat treatment eliminated the silane by-products and } \\
\text { helped complete the reaction between silane and silica. } \\
\text { The study showed that the heat treatment of the silane at } \\
77^{\circ} \mathrm{C} \text { had a positive effect on the interfacial bond strength, } \\
\text { which was not affected by mechanical cycling ( } 200,000 \\
\text { cycles). Prior to aging, heat treatment of silanized } \\
\text { feldspathic ceramic demonstrated the bond strength } \\
\text { similar to that obtained with hydrofluoric-acid-etching } \\
\text { treatment but of lower bond strength after aging. }\end{array}$ & [73] \\
\hline $\begin{array}{l}\text { Aminopropyldimethylethoxy } \\
\text { Silane } \\
\text { (APDMES) }\end{array}$ & Zirconia (Y-TZP) & $\begin{array}{l}\text { Silanization was purposeful, but it yielded slightly lower } \\
\text { densities of APDMES on the modified surfaces of zirconia } \\
\text { than on typical silica substrates; no adverse effect of } \\
\text { silanization was found on the mechanical response of the } \\
\text { treated samples; the modification techniques only took } \\
\text { part on the surface, without creating critical surface } \\
\text { defects or anyhow damaging the structure, which is } \\
\text { crucial for zirconia low thermal degradation }\end{array}$ & {$[74]$} \\
\hline
\end{tabular}

The main disadvantage of this surface modification method is randomly distributed groups of silicon oxides on the ceramic surface, which adsorb water as a hydroxyl group, forming a weak hydrogen bond [69]. It is also possible that other oxides present on ceramic surface absorb or adsorb water. There is a kind of competition between silane and water at available bond sites [69]. The polycondensation of bifunctional silane monomers with the general formula of (R-O-) 3-Si-O-R, R being the first and $\mathrm{O}-\mathrm{R}$ the second silane functionality, can provide a highly cross-linked and reactive polyorganosiloxane layer to ceramics [69]. However, their hydrolytic degradation is still of concern [3-6]. Therefore, attempts are made to increase their cross-linking [69]. A proven method to prevent the mentioned adverse phenomenon is to obtain cross-linking by HF etching or by heat treatment. The HF etching se- lectively removes the glassy matrix which consequently promotes surface roughening, and micromechanical retention is facilitated to obtain a proper adhesive $[69,70]$. However, the HF etching is harmful, due to the HF toxicity and a negative effect on some ceramics, in which HF produces insoluble silica-fluoride salts that can interfere with the resin bond. Some high-crystalline ceramics may not benefit from the HF etching [69]. As opposed to the above, heat treatment after silanization promotes the improvement of the adhesion of silane layers to ceramics. Heat treatment procedures reduce solvents and enhance the cross-linking reaction [69]. The cross-linking is found to increase from the outer layers of the silane toward the glass surface with the corresponding increase in the mechanical and hydrothermal stability of silane [69]. In figure 
(Figure 4), the image schematically shows a representation of silanization on the ceramic surface.

The table (Table 6) below presents the collected data on silanization, silanization agents, and the possibility of surface modification with these processes.

\subsection{Thermal Treatment}

The thermal treatment of ceramics is the oldest method of ceramics processing. It allows, depending on the time, firing temperature, and gas atmosphere to receive ceramics with different physical and chemical properties, including different phase composition, porosity, and surface morphology [75]. Much attention is given to the burning of ceramics and its impact on the structure, phase composition, and morphology of surfaces of ceramics used in prosthetic dentistry [76-78]. Lithium disilicate glass-ceramics for example, are composed of the interlocking microstructure of the glass matrix and crystalline phase. The microstructure providing an effective strengthening and aesthetic performance of artificial teeth, is produced by controlled crystallization of various components obtained in controlled heat treatments [78]. Many investigations have shown that heat treatments are associated with the structural and mechanical changes of the ceramic, and the mechanical proper- ties of lithium disilicate glass-ceramics depended on microstructure $[79,80]$.

Similar to the other kind of ceramics, the resin bonding of ceramic is widely accepted to depend both on the micro-mechanical retention achieved by the ceramic surface roughening, and the chemical bonding between the chemically active ceramic surface and the resin matrix in resin cement [78]. In order to provide proper ceramic retention and adhesion, the surface should be roughened. The gold standard for biomedical applications is the use of dilute hydrofluoric acid [81], also described earlier in this paper. The best way to ensure the retention of ceramics into resins seems to be the combination of chemical etching, surface chemical activation e.g., by silanization, and a thermal process that is correctly carried out. For example, for the lithium disilicate glass-ceramic with HF, the etching is based on the mechanism of the HF acid reacting with silica in a ceramic substance to form a soluble fluorosilicate, since the glass phases and crystalline phases in lithium disilicate glass-ceramic would be restructured and rearranged in the crystallization process of the heat treatment [78]. It still must be investigated if different firing cycle times might lead to microstructure changes, and whether the microstructure changes would further affect the acid resistance [78].

A critical problem in the implementation of surface modification through thermal collectors is the heating

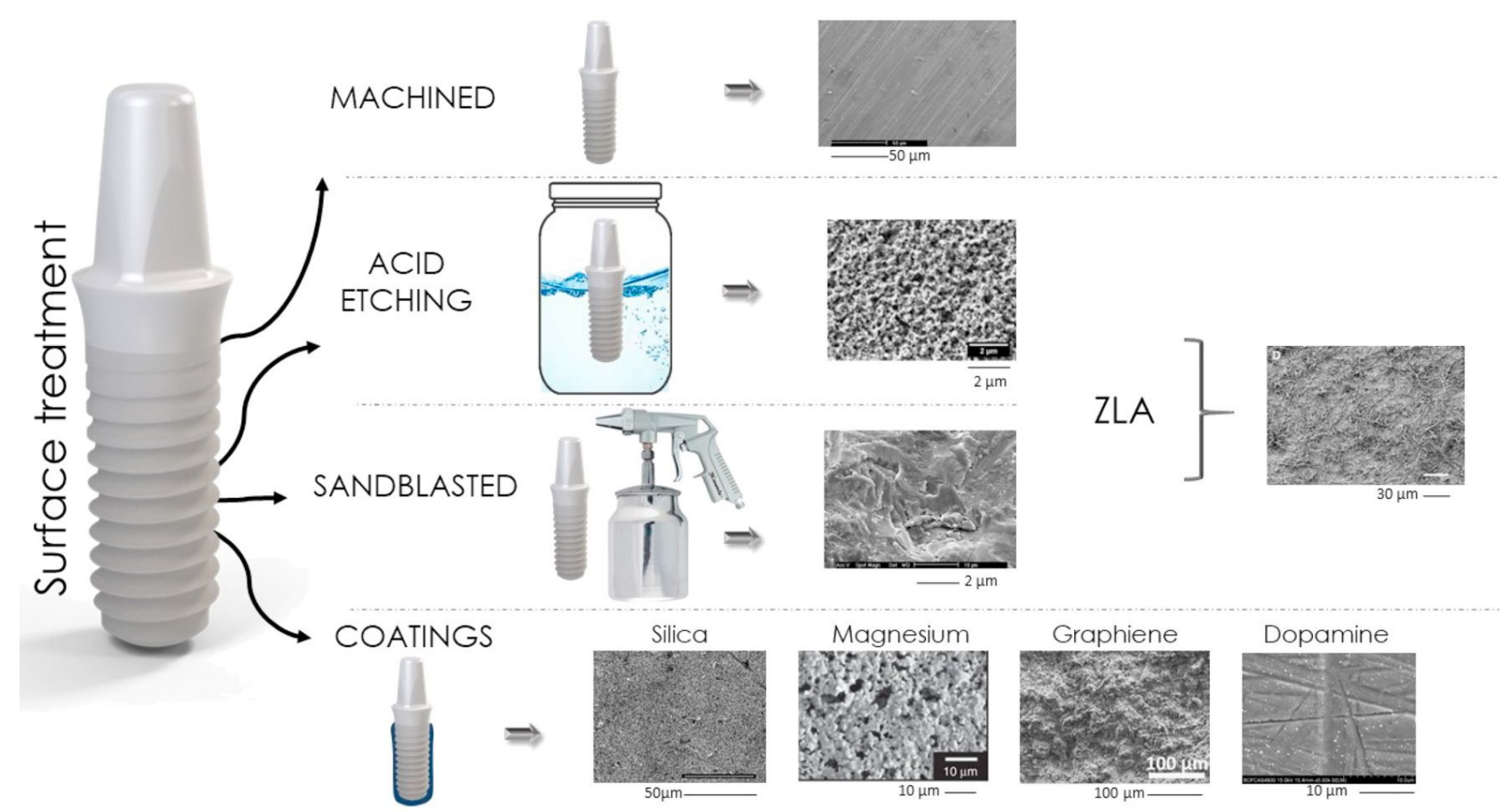

Figure 5: Schematics and SEM images on different zirconia surface modifications: the machined, acid-etched, grit-blasted, ZLA and multilayered coatings [83] 
Table 7: Influence of thermal treatment for bioceramic surface modification

\begin{tabular}{|c|c|c|c|}
\hline $\begin{array}{c}\text { Type of } \\
\text { bioceramics }\end{array}$ & Surface treatment & Characteristics & Ref. \\
\hline Zirconia & $\begin{array}{l}\text { thermal treatment } \\
\text { associated with } \\
\text { sandblasting, hydrofluoric } \\
\text { etching, and surface layer } \\
\text { deposition, combined } \\
\text { thermal methods with other } \\
\text { methods give the lowest } \\
\text { effects of surface } \\
\text { development, adhesion } \\
\text { poring and ensuring proper } \\
\text { ceramic retention (Figure 5). }\end{array}$ & $\begin{array}{l}\text { grit blasting, acid etching, and heat treatment do not } \\
\text { negatively influence the mechanical properties of } \\
\text { zirconia such as flexural strength and fracture } \\
\text { toughness; smooth and round shape particles for grit } \\
\text { blasting are recommended to avoid micro-crack } \\
\text { formation of ceramics structure; many investigations } \\
\text { have shown that the high HF concentrations, } \\
\text { over-etching time and thermal treatment with improper } \\
\text { cooling rate especially with nucleation of zirconia } \\
\text { monoclinic phase, are not recommended since they can } \\
\text { increase zirconia degradation and cause damage to the } \\
\text { ceramic surface; the key factor for zirconia is the } \\
\text { selection of thermodynamic parameters for thermal } \\
\text { treatment and applied layers in way to not allow to } \\
\text { decrease the activation energy of martensitic } \\
\text { transformation which negatively impacts the resistance } \\
\text { to aging at lower temperatures, especially in the human } \\
\text { body environment. }\end{array}$ & $\begin{array}{c}{[14,83-} \\
85]\end{array}$ \\
\hline
\end{tabular}

method and the ceramics exposure times to the high temperature. Here, the SPS or Spark Plasma Sintering allows for the explosion time reduction, the process costs reduction, and for smooth regulation of the thermal device influence, among others, on the phase compositions and surface roughness of ceramics [82].

The thermal modification basically occurs as a modification associated with other methods, primarily applying layers of e.g., silicon, magnesium, graphene, or as a finishing cloth for chemical etching mostly with hydrofluoric acid [83]. As in the previous paragraphs, the information on the methods of modifying the ceramic surface is provided in the table below (Table 7). It is very puzzling for us that although firing or thermal treatment is the oldest way to process ceramics, not much information on the surface treatment process has been confirmed or validated yet. A lot of data can be found about the process itself or the new methods, but the information on the impact of the heat treatment on the ceramic surface is scarce [86-89].

The collected dates concern the most widely used type of ceramics used as biomaterial - zirconia

\subsection{Ionic Liquid Treatment}

Modification of the ceramic surface with ionic liquids is particularly important in applying active stimulants, for example, osseitration or in bactericidal and bacteriostatic activity $[90,91]$. The use of modifications with ionic liquids is advantageous because it allows us to partially eliminate the risks involved in the use of ceramic biomaterials. In zircon bioceramics continuous exposure of the mouth to moist for instance, temperature fluctuations and $\mathrm{pH}$ variation [91] intrinsic dental degradation occur [91]. Additionally, beverages and protein adsorption are one of the most common extrinsic factors that cause dental prosthesis degradation. Bearing this in mind is particularly important when considering long-lasting functional prostheses with $\mathrm{ZrO}_{2}$ in an unfavorable environment with co-existing conditions, e.g. bruxism $[92,92]$.

The authors' own experience regarding the $\mathrm{ZrO}_{2}$ resistance to the so-called low-temperature degradation shows that only doping of metastable $\mathrm{ZrO}_{2}$ phases or applying active coatings can be a solution to the problem of destruction of ceramics in the body environment [92-94]. Beverages enriched with various acids, such as tartaric acid, malic acid, lactic acid, ascorbic acid, citric acid, and phosphoric acid have a strong destructive effect on teeth surface and dentures made from ceramics [91]; what is more, bruxism could be destructive for dentures [95] as well.

Given their low volatility, good ionic conductivity, excellent thermal and electrochemical stability, low flammability and toxicity, ionic liquids (IL) are widely used to coat the surfaces of medical devices and implants [87]. They 
Table 8: Ceramics biomaterials used for biomedical application

\begin{tabular}{ccc}
\hline Ceramics & Applications & Ref. \\
\hline Calciumsuphate and & Bone defects filler, orthopedics and dentistry & {$[105]$} \\
carbonate & Dentistry, arthroplasty, animicrobalactivities & {$[106,107]$} \\
Alumina ceramics & Dentistry, HA stabilizer, metal lic implants coating & {$[108]$} \\
Zirconia ceramics & Replacing a vertebral body, material coatings, orthopedic applications & {$[109]$} \\
Bioactive Glass ceramics & Bone repairing devices, drug delivery, modifier for synthetic and & {$[110-112]$} \\
Silicate bioactive glasses & natural polymers & \\
\hline
\end{tabular}

are organic salts, consisting of an organic cation and either an inorganic or organic anion that is liquid below $100^{\circ} \mathrm{C}$. It has been reported recently that IL ions tend to decompose under thermal and mechanical stresses and then react with various both metallic and ceramic surfaces to form protective films $[25,96,97]$.

The deposition of ionic liquid layers on the ceramic surface is also crucial in obtaining an excellent chemical connection with the resin in ceramic-polymer composites. The issue is particularly vital because ceramics as chemically indifferent can be combined with polymers only as a result of mechanical connection. The key is the chemical bond between the ceramic filler and the resin, and the selection of the appropriate curing agent that will ensure this. The wide variety of available curing agents and the different curing conditions denote it is possible to obtain epoxy resins with many different physical properties such as toughness, chemical resistance [98], mechanical properties which range from extreme flexibility to high strength and hardness, top adhesive strengths, excellent heat resistance, high tensile, flexural, and compressive strength [98]. The application of imidazole ionic liquid as a curing agent in epoxy resins is a good example. Imidazoles are very useful curing agents and combined with epoxy resins, yield adhesives, and coatings with very good mechanical properties. Studies have also shown that epoxy resins cured with imidazoles can have excellent physical properties such as better heat resistance, lower tensile elongation, and higher modulus [98, 99]. Structurally related imidazolium-based ionic liquids provide one of the most studied groups of ionic liquids and they are often selected due to the stability of the ring in oxidative and reductive environments, the low viscosity, and the relative ease of synthesis [98].

The table below presents data on the application of active and functional layers to the ceramic surface to improve the adhesion between ceramic and polymer (Table 8). Nevertheless, papers in this field are very few, and in principle, single papers were chosen. Due to the disadvantages of each group of materials, both polymers, and ceramics used separately as biomaterials in the context of the composites replacement use, seem to be crucial in the field of biomaterials engineering.

\section{Perspectives of the use of polymer-ceramic composites and cenospheres applications in biomedical engineering}

Polymers and polymer-based composites have found applications as matrices or degrading carriers in the human body or as a construction biomaterial. A composite is a material structure consisting of two or more identifying components that work together to achieve better biomaterial properties. The composite is a material composed of two phases: a dispersed phase and a matrix phase. The composites offer innovative features that differ from individual components. Composite materials have promising properties such as corrosion resistance, lightweight, and high fatigue strength [102]. The composite materials with excellent properties and a variety of applications are considered promising research and development materials. In the context of biological applications, polymer composites have many advantages, such a low cost and the use of available natural and synthetic matrices as well as ease and ability to choose manufacturing techniques [103].

The production of composite materials with the use of cenospheres in biomedical engineering is predominantly used in dental prosthetics and epithesis. The composite material combines the advantages of ceramics and polymers and meets the clinical environment expectations regarding biomaterials with high mechanical strength as well as ease of use during the implantable procedure.

Many clinical applications such as the treatment of orthopedic disorders are of interest in the field of tissue 
engineering. Bone disorders are becoming one of the top health problems in the world, especially for the elderly. For the repair and treatment of damaged hard tissues, various types of biomaterials and implants in damaged bone parts have been widely used. The ceramics group, due to its biocompatibility and bone structure similarity is a favorable group of biomaterials. Ceramic materials based on calcium phosphate, including $\beta$-TCP and HAp, are mainly used in orthopedic and dental applications [104]. The use of calcium phosphate-based biomaterials includes bone reconstruction, coating of orthopedic implants, dental use, and drug delivery. The table shows the use of ceramic biomaterials for biomedical applications.

In recent years, the range of polymers for bone tissue engineering applications has been studied widely. However, due to the modifiable properties of most synthetic polymers such as PLA, PLLA, PDLA, PDLLA, PLGA which exhibit biodegradability, biocompatibility, and ease of processing [113], as well as polyurethanes, polyetheretherketone (PEEK), anspolumethyl methacrylate (PMMA) which offer excellent possibilities usage, the biodegradable polymers can be used to heal wounds, in implants, in dental or cardiovascular applications, drug delivery, and tissue engineering [114]. Both natural and synthetic polymers significantly contribute to modern medicine. The biodegradable polymer applications eliminate the need for surgery to remove an implant, as well as bone regeneration by osteoblasts through the progressive degradation of the implant material or biodegradable material that can eliminate the need for bone plates and screws in bone stabilization.

The polymer-ceramic composites based on polymers and hydroxyapatite are used as implants for bone fixation, i.e. sutures, interference screws and for meniscus repair [115].

The polymer-ceramic composites under the ongoing research are deemed to be included in the third generation orthopedic biomaterials due to their ability to closely match the properties of natural bone, in comparison with the first and second generation bone substitute materials. The combination of polymers and ceramic phases leads to improved mechanical properties due to the natural higher rigidity and strength of the inorganic material. Therefore, in applications where stiffness and skill suppression such as of the bone is required, modification of polymers with ceramic particles can be an interesting solution [116]. The addition of micro and nano-hydroxyapatite to synthetic polymers results in mechanical properties comparable to the skeleton of bone formation [117]. Furthermore, the addition of bioactive phases to bioresorbable polymers may change the degradation of the polymer composite scaf- folds. The development of such composite materials for biomedical applications is attractive due to the possibility of adapting to the tissue mechanical and physiological requirements, controlling the volume fraction, morphology and arrangement of the reinforcing phase. Literature reports show that highly porous scaffolds made of polymer ceramic composites seem to be a promising substrate for bone tissue due to their excellent mechanical properties and the osteoconductivity [118]. As a kind of structure consisting of a composite of ceramic and polymer materials, they are widely used for bone expansion and repair. Polyethylene (PE), poly(methylmethacrylate) (PMMA), poly(propylene fumarate) (PPF), as well as chitosan can be used as polymeric materials. Hydroxyapatite (HA)-reinforced high-density polyethylene composite has been developed as an analogy to bone replacement and support material in joint endoprostheses. The HA presence in the composite ensures the polymer mechanical strengthening, creep resistance improvement, along with inherent bioactivity and biocompatibility [119].

Poly(methylmethacrylate) is known as polymer material for bone reconstruction. PMMA-based bone types of cement made of a powdered component consisting of PMMA polymer or similar block copolymers and a liquid component made of methyl methacrylate or the related monomer liquids are currently available. This type of composite is used, among others, in cutaneous vertebroplasty in the treatment of fractures and spinal changes [116, 120, 121]. Biodegradable polymer composites are new developments in bone disease treatment and fracture repair. They can be used for orthopedic implants such as inter somatic cages for spinal arthrodesis and osteosynthesis plater in fractures healing. Therefore, it is essential to obtain the optimum mechanical properties, bioactivity, and biodegradability in the design and development of the biodegradable polymer composites [116]. Jayabalan et al. have studied a poly(propylene fumarate) copolymer with hydroxtapatite as bone cement and found it to be an ideal candidate for use in orthopaedic surgery [122].

The PLGA- and hydroxyapatite-based composites are used, while the PLGA polymer has poor mechanical properties and bioactivity which may not ensure stable osseointegration. Mao et al. studied the composite scaffold PLGA/etyl cellulose/ HA as load substitutes. The mechanical performance of scaffolds was improved by combining robust leaching methods, and the mechanical and hydrophilic properties of the composites improved after the introduction of hydroxyapatite [123]. Ceramics can be used as a polymer coating to solve the mentioned problems [124]. 
Mixing polymer and ceramics at the molecular level can be considered a method to overcome the fragility of ceramics while increasing the strength of the polymer. The classic approach to combining polymer and ceramics is to incorporate ceramic particles into a polymer matrix. The resulting materials have better strength, elastic properties and tribological resistance [125-128].

The table presents ceramic-polymer composites used in various biomedical applications.

Table 9: Ceramic-polymer composites used in biomedical applications

\begin{tabular}{ccc}
\hline Applications & CompositeMaterial & Ref. \\
\hline Bone & $\begin{array}{c}\text { Poly(lactide-co-glycolide) } \\
\text { (PLGA)/ calcium phospate }\end{array}$ & {$[129]$} \\
& PLA/ethyl cellulose & {$[123]$} \\
& (EC)/hydroxyapatite & \\
Oral tissue & Hydroxyapatite/PLA & {$[130]$} \\
Wound dressing & Kaolin/polyurethane & {$[131]$} \\
\hline
\end{tabular}

The ceramic-polymer composites are also used in dentistry. In addition to the use of the hydroxyapatite/PLA composite for bone-cartilage implants for repair of the temporomandibular joint, it also has other applications in dentistry. The use of composites in dentistry is a perspective for permanent tooth fillings. The microstructure of these composite materials consists of a polymer matrix and ceramic reinforcing particles. Mixing polymer and ceramics at the molecular level will overcome the fragility of ceramics while increasing the strength of the polymer. The classic approach is to combine ceramics with a polymer by incorporating ceramic particles into the polymer matrix [132]. The resulting material has improved strength, elastic properties, and tribological resistance. Resin-based composite materials reinforced with ceramic particles are most commonly used for dental restorations [133-136].

Recently, promising dental materials have been the development of polymer-infiltrated ceramic network composites (PICN), adjusting the performance of individual components, consisting of two elements, a porous sintered ceramic matrix ( $86 \%$ by weight) and an infiltered polymer (14\% by weight) [137]. The PICN material process involves two stages: a porous pre-sintered ceramic is formed, and then the porous ceramic network is infiltrated with a polymer. Before infiltrating the resin, the ceramic network is conditioned with the coupling agent, and the polymer network is chemically crosslinked with the ceramic network to form a mutual permeation network system [137]. Li et al. suggested a composite consisting of a zirconia and poly(methylmethacrylate) $\mathrm{PMMA}^{-\mathrm{ZrO}_{2}}$ prepared from the resin-infiltrated ceramic. They expect it to be used as dental CAD/CAM material. Such commercially available hybrid resin composite obtained in infiltrating a monomer mixture into a pre-sintered ceramic network is called Vita Enamic [138, 139]. Hybrid ceramicpolymer composites produced by infiltrating the polymer resin with a ceramic material with a hierarchical structure give the possibility of possible indirect restorations imitating the even structure of dentin tubules and restore the function of anisotropy [140, 141]. The method of infiltrating monomers into a porous ceramic can limit the introduction of a large number of ceramic fillers into the polymer matrix by conventional mixing. Appropriate design of materials and selection of processing techniques can improve the microstructure geometry and mechanical properties of hybrid ceramic composites infiltrated with polymers.

\section{References}

[1] Alba, R. A., D. Borrás, A. I. Muñoz, C. Richard, and G. Manivasagam. Degradation mechanisms and future challenges of titanium and its alloys for dental implant applications in oral environment. Materials Science and Engineering C, Vol. 76, 2017, pp. 1354-1368.

[2] Frutos, E., D. Álvarez, L. Fernandez, and J. L. González-Carrasco. Effects of bath composition and processing conditions on the microstructure and mechanical properties of coatings developed on 316 LVM by hot dipping in melted AISi alloys. Journal of Alloys and Compounds, Vol. 617, 2014, pp. 646-653.

[3] Jin, W., G. Wang, A. M. Qasim, S. Mo, Q. Ruan, H. Zhou, W. Li, and P. K. Chu. Corrosion protection and enhanced biocompatibility of biomedical Mg-Y-RE alloy coated with tin dioxide. Surface and Coatings Technology, Vol. 357, 2019, pp. 78-82.

[4] Manam, N. S., W. S. W. Harun, D. N. A. Shri, and J. All. Study of corrosion in biocompatible metals for implants: A review. Journal of Alloys and Compounds, Vol. 701, 2017, pp. 698-715.

[5] Bogdanski, D., M. Epple, S. A. Esenwein, G. Muhr, V. Petzoldt, O. Prymak, et al. Biocompatibility of calcium phosphate-coated and of geometrically structured nickel-titanium (NiTi) by in vitro testing methods. Materials Science and Engineering A, Vol. 378, No. 1-2, 2004, pp. 527-531.

[6] Chakraborty, R., and P. Saha. Surf. Inter., Vol. 12, 2018, pp. 160167.

[7] Ding, S.-J. Y-H Chu, D-Y. Wang D-Y. Applied Materials Today, Vol. 9, 2017, pp. 622-632.

[8] Menini, M., P. Pesce, F. Pera, F. Barberis, A. Lagazzo, L. Bertola, et al. Biological and mechanical characterization of carbon fiber frameworks for dental implant applications. Materials Science and Engineering C, Vol. 70, No. 1, 2017, pp. 646-655.

[9] Schwitalla, A. D., T. Zimmermann, T. Spintig, M. Abou-Emara, J. Lackmann, W. D. Müller, et al. Maximum insertion torque of a novel implant-abutment-interface design for PEEK dental implants. Journal of the Mechanical Behavior of Biomedical Materi- 
als, Vol. 77, Jan. 2018, pp. 85-89.

[10] Brum, R. S., P. R. Monich, F. Berti, M. C. Fredel, L. M. Porto, C. A. M. Benfatti, et al. On the sulphonated PEEK for implant dentistry: Biological and physicochemical assessment. Materials Chemistry and Physics, Vol. 223, 2019, pp. 542-547.

[11] Zhao, W., L. Liu, F. Zhang, J. Leng, and Y. Liu. Shape memory polymers and their composites in biomedical applications. Materials Science and Engineering C, Vol. 97, 2019, pp. 864-883.

[12] Nakonieczny, D., W. Walke, J. Majewska, and Z. Paszenda. Characterization of magnesia-doped yttria-stabilized zirconia powders for dental technology applications. Acta of Bioengineering and Biomechanics, Vol. 16, No. 4, 2014, pp. 99-106.

[13] Nakonieczny, D. S., M. Antonowicz, Z. K. Paszenda, T. Radko, S. Drewniak, W. Bogacz, and C. Krawczyk. Acta of Bioengineering and Biomechanics, Vol. 38, No. 3, 2018, pp. 535-543.

[14] Nakonieczny, D. S., A. Ziębowicz, Z. K. Paszenda, and C. Krawczyk. Trends and perspectives in modification of zirconium oxide for a dental prosthetic applications - A review. Biocybernetics and Biomedical Engineering, Vol. 37, No. 1, 2017, pp. $229-$ 245.

[15] Ranjbar, N., and Kuenzel C. Cenospheres: A review. Fuel. Vol. 207, 2017, pp. 1-12.

[16] Puri, R. G., and Khanna A. S. Effect of cenospheres on the char formation and fire protective performance of water-based intumescent coatings on structural steel. Progress in Organic Coatings, Vol. 92, 2016, pp. 8-15.

[17] Shahapurkar, K., C. D. Garcia, M. Doddamani, G. C. Mohan Kumar, and P. Prabhakar. Compressive behavior of cenosphere/epoxy syntactic foams in arctic conditions. Composites Part B: Engineering, Vol. 135, 2018, pp. 253-262.

[18] Kumar, R., D. P. Mondal, A. Chaudhary, et al. Comp. A. Applied Science and Manufacturing, Vol. 112, 2018, pp. 475-484.

[19] Balnco F., P. Garcıá, P. Mateos, and J. Ayala. Characteristics and properties of lightweight concrete manufactured with cenospheres. Cement and Concrete Research, Vol. 30, No. 11, 2000, pp. $1715-1722$.

[20] Rohatgi P. K., J. K. Kim, S. Alaraj, and A. Daoud. Compressive characteristics of A356/fly ash cenosphere composites synthesized by pressure infiltration technique. Composites. A. Applied Science and Manufacturing, Vol. 37, No. 3, 2006, pp. 430-437. 22, 25-27

[21] Karlsson, M. C. F., Z. Abbas, R. Bordes, Y. Cao, A. Larsson, A. Rolland, P. Taylor, and B.-M. Steenari. Surface properties of recycled titanium oxide recovered from paint waste. Progress in Organic Coatings, Vol. 125, 2018, pp. 279-286.

[22] Janson, O., S. Gururaj, S. Pujari-Palmer, M. Karlsson Ott. M. Strømme, H. Engqvist, et al. Titanium surface modification to enhance antibacterial and bioactive properties while retaining biocompatibility. Materials Science and Engineering C, Vol. 96, 2019, pp. 272-279.

[23] Sokol, E. V., N. V. Maksimova, N. I. Volkovs, E. N. Nigmatulina, and A. E. Frenkel. Hollow silicate microspheres from fly ashes of the Chelyabinsk brown coals (South Urals, Russia). Fuel Processing Technology, Vol. 67, No. 1, 2000, pp. 35-52.

[24] Sarkar, A., R. Rano, K. K. Mishra, and A. Mazumder. Characterization of Cenospheres Collected from Ash-pond of a Super Thermal Power Plant. Energy Sources, Part A: Recovery, Utilization, and Environmental Effects, Vol. 30, No. 3, 2007, pp. 271-283.

[25] Valentim, B., N. Shreya, Biswajit Paul, Celeste Santos Gomes, H. Sant'Ovaia, A. Guedes, et al. Characteristics of ferrospheres in fly ashes derived from Bokaro and Jharia (Jharkand, India) coals. International Journal of Coal Geology, Vol. 153, No. 50, 2016, pp. 52-74.

[26] Sokol, E. V., V. M. Kalugin, E. N. Nigmatulina, N. I. Volkova, A. E. Frenkel, and N. V. Maksimova. Ferrospheres from fly ashes of Chelyabinsk coals: chemical composition, morphology and formation conditions. Fuel, Vol. 81, No. 7, 2002, pp. 867-876.

[27] Basiaga, M., W. Walke, D. Nakonieczny, and A. Hyla. Physiochemical properties of TiO2 nanoparticle thin films deposited on stainless steel. Metalurgija, Vol. 56, No. 1-2, 2017, pp. 171-174.

[28] Romanov, D. A., K. V. Sosnin, V. E. Gromov, V. A. Bataev, Y. F. Ivanov, A. M. Glezer, et al. Titanium-zirconium coatings formed on the titanium implant surface by the electroexplosive method. Materials Letters, Vol. 242, 2019, pp. 79-82.

[29] Newcomb, B. A. Processing, structure, and properties of carbon fibers. Applied Science and Manufacturing, Vol. 91, No. 1, 2016, pp. 262-282.

[30] Chung, D. L. Processing-structure-property relationships of continuous carbon fiber polymer-matrix composites. Materials Science and Engineering R Reports, Vol. 113, 2017, pp. 1-29.

[31] Beggs, K. M., J. D. Randall, L. Servinis, A. Krajewski, R. Denning, and L. C.Henderson. Increasing the resistivity and IFSS of unsized carbon fibre by covalent surface modification. Reactive and Functional Polymers. 129, 2018, pp. 123-128.

[32] Wang, K., M. Li, Y. Q. Liang, J. Wang, L. He, S. Y. Du, et al. Interface modification of carbon fibers with TiC/Ti2AIC coating and its effect on the tensile strength. Ceramics International, Vol. 45, No. 4, 2019, pp. 4661-4666.

[33] Al Aiti, M., D. Jehnichen, D. Fischer, H. Brünig, and G. Heinrich. On the morphology and structure formation of carbon fibers from polymer precursor systems. Progress in Materials Science, Vol. 98, 2018, pp. 477-551.

[34] Yao, S.-S., F.-L. Jin, K. Y. Rhee, D. Hui, and S.-J. Park. Recent advances in carbon-fiber-reinforced thermoplastic composites: $A$ review. Composites: $B$ Engineering, Vol. 142, 2018, pp. 241-250.

[35] Yao, X., X. Gao, J. Jiang, C. Xu, C. Deng, and J. Wang. Comparison of carbon nanotubes and graphene oxide coated carbon fiber for improving the interfacial properties of carbon fiber/epoxy composites. Composites: B Engineering, Vol. 132, No. 1, 2018, 75 pp. $170-177$.

[36] Hung, P.-y., K.-t. Lau, B. Fox, N. Hameed, J. Hee Lee, and D. Hui. Surface modification of carbon fibre using graphene-related materials for multifunctional composites. Composites: B Engineering, Vol. 133, 2018, pp. 240-257.

[37] Baino, F. Porous glass-ceramic orbital implants: A feasibility study. Materials Letters, Vol. 212, 2018, pp. 12-15.

[38] Xu, S., and Q. Jiang. Surface modification of carbon fiber support by ferrous oxalate for biofilm wastewater treatment system. Journal of Cleaner Production, Vol. 194, 2018, pp. 416-424.

[39] Newcomb, B. A. Processing, structure, and properties of carbon fibers. Composites Part A: Applied Science and Manufacturing, Vol. 91, 2016, pp. 262-282.

[40] Q. Cai, K. Subramani, R. Mathew, and X. Yang. Carbon nanomaterials for Implant Dentistry and bone tissue engineering, Nanobiomaterials in Clinical Dentistry, 2nd ed., 2019, pp. 429-468.

[41] Sha, J. J., J. Li, S. H. Wang, Y. C. Wang, Z. F. Zhang, and J. X. Dai. Toughening effect of short carbon fibers in the $\mathrm{ZrB}_{2}-\mathrm{ZrSi}_{2}$ ceramic composites. Materials \& Design, Vol. 75, 2015, pp. 160 165. 
[42] Lin J., X. H. Zhang, Z. Wang, W. Han, and H. Jin. Microstructure and mechanical properties of hot-pressed $\mathrm{ZrB2}-\mathrm{SiC}-\mathrm{ZrO} 2 \mathrm{f}$ ceramics with different sintering temperatures. Materials \& Design, Vol. 34, 2012, pp. 853-856.

[43] Cho, B.-G., S.-H. Hwang, M. Park, J. K. Park, Y.-B. Park, and H. G. Chae. The effects of plasma surface treatment on the mechanical properties of polycarbonate/carbon nanotube/carbon fiber composites. Compo. B, Vol. 160, 2019, pp. 436-445.

[44] Tsai, S.-N., D. Carolan, S. Sprenger, and A. C. Taylor. Fracture and fatigue behaviour of carbon fibre composites with nanoparticlesized fibres. Composite Structures, Vol. 217, 2019, pp. 143-149.

[45] Gao, T., Y. Zhao, G. Zhou, Y. Han, Y. Zheng, Z. Shan, et al. Fabrication and characterization of three dimensional woven carbon fiber/silica ceramic matrix composites. Compo. B, Vol. 77, 2015, pp. 122-128.

[46] Zhang, W., X. Deng, G. Sui, and X. Yang. Improving interfacial and mechanical properties of carbon nanotube-sized carbon fiber/epoxy composites. Carbon, Vol. 145, 2019, pp. 629-639.

[47] Cho, B.-G., S.-H. Hwang, M. Park, J. K. Park, Y.-B. Park, and H. G. Chae. The effects of plasma surface treatment on the mechanical properties of polycarbonate/carbon nanotube/carbon fiber composites. Composites Part B: Engineering, Vol. 160, 2019, pp. 436-445.

[48] Fu, J., M. Zhang, L. Jin, L. Liu, N. Li, L. Shang, et al. Enhancing interfacial properties of carbon fibers reinforced epoxy composites via Layer-by-Layer self assembly $\mathrm{GO} / \mathrm{SiO}_{2}$ multilayers films on carbon fibers surface. Applied Surface Science, Vol. 470, 2019, pp. 543-554.

[49] Wei, J., B. Lin, H. Wang, T. Sui, S. Yan, F. Zhao, et al. Friction and wear characteristics of carbon fiber reinforced silicon carbide ceramic matrix ( $\mathrm{Cf} / \mathrm{SiC}$ ) composite and zirconia $\left(\mathrm{ZrO}_{2}\right)$ ceramic under dry condition. Tribology International, Vol. 119, 2018, pp. 45-54.

[50] Inoue, R., Y. Arai, Y. Kubota, K. Goto, and Y. Kogo. Development of short- and continuous carbon fiber-reinforced ZrB2-SiC-ZrC matrix composites for thermal protection systems. Ceramics International, Vol. 44, No. 13, 2018, pp. 15859-15867.

[51] Song, B., T. Wang, L. Wang, H. Liu, X. Mai, X. Wang, et al. Interfacially reinforced carbon fiber/epoxy composite laminates via in-situ synthesized graphitic carbon nitride (g-C3N4). Compo. B, Vol. 158, 2019, pp. 259-268.

[52] Cao, J. J., H. H. Chen, F. Du, H. C. Zhao, and L. Fan. Preliminary study of in situ transformed carbon fibers $/ \mathrm{Al}_{2} \mathrm{O}_{3}$ ceramic matrix composites. Ceramics International, Vol. 39, No. 6, 2013, pp. 7037-7042.

[53] Zhu, L., S. Zeng, Z. Teng, H. Luo, X. Han, C. Chen, et al. Significantly enhanced electromagnetic interference shielding in Al203 ceramic composites incorporated with highly aligned nonwoven carbon fibers. Ceramics International, Vol. 45 (10), 2019, pp. 12672-12676.

[54] Sufang, T., and H. Chenglong. Design, preparation and properties of carbon fiber reinforced ultra-high temperature ceramic composites for aerospace applications: A Review. Journal of Materials Science and Technology, Vol. 33, 2017, pp. 117-130.

[55] Nishihara, H., and M. H. Adanez. Current status of zirconia implants in dentistry: preclinical tests. Journal of Prosthodontic Resarch, Vol. 63, No. 1, 2019, pp. 1-14.

[56] Schunemann, F. H., M. E. Galarraga-Vinueza, R. Magini, M. Fredel, F. Silva, J. C. M. Souza, Y. Zhang, and B. Henriques. Zirconia surface modifications for implant dentistry. Materials Science and Engineering C, Vol. 98, 2019, pp. 1294-1305.

[57] Scarano, A., M. Piattelli, S. Caputi, G. A. Favero, and A. Piattelli. Bacterial adhesion on commercially pure titanium and zirconium oxide disks: An in vivo human study. Journal of Periodontology, Vol. 75, No. 2, 2004, pp. 292-296.

[58] Alizadeh-Osqouei, M., Y. Li, and C. Wen. A comprehensive review of biodegradable synthetic polymer-ceramic composites and their manufacture for biomedical applications. Bioactive Materials, Vol. 4, No. 1, 2019, pp. 22-36.

[59] Jayasuriya, C. K. Interfacial bonding in polymer-ceramic nanocomposites. Reference Module in Materials Science and Materials Engineering, 2017. DOI: https://doi.org/10.1016/B9780-12-803581-8.03252-5.

[60] Schneck, T. K., B. Brück, M. Schulz, J. M. Spörl, F. Hermanutz, and B. Clauß. Carbon fiber surface modification for tailored fibermatrix adhesion in the manufacture of $\mathrm{C} / \mathrm{C}$-SiC composites. Composites $A$, Vol. 120, 2019, pp. 64-72.

[61] Gabouze, N., A. Keffous, T. Kerdaja, et al. Chemical etching investigation of polycrystalline p-type $6 \mathrm{H}-\mathrm{SiC}$ in $\mathrm{HF} / \mathrm{Na} 2 \mathrm{O} 2$ solutions. Applied Surface Science, Vol. 255, No. 15, 2009, pp. 6751-6756.

[62] Sato, H., and T. Homma. Fabrication of high-aspect-ratio arrayed structures using Si electrochemical etching. Science and Technology of Advanced Materials, Vol. 7, No. 5, 2006, pp. 468-474.

[63] Tsujimoto, A., W. W. Barkmeier, T. Takamizawa, T. M. Wilwerding, M. A. Latta, and M. Miyazaki. Interfacial characteristics and bond durability of universal adhesive to various substrates. Operative Dentitry, Vol. 42, No. 2, 2017, E59-E70.

[64] Sattabanasuk, V., P. Charnchairerk, L. Punsukumtana, and M. F. Burrow. Effects of mechanical and chemical surface treatments on the resin-glass ceramic adhesion properties. Journal of Ivestigative and Clinical Dentistry, 2016, 1-9.

[65] Sharma, J. R., S. Bose, S. Mandal, G. Das, S. Mukhopadhyay, and A. K. Barua. Influence of acid and alkali etching on sputtered aluminium doped zinc oxide films. Materials Today: Proceedings, Vol. 5, 2018, pp. 9726-9732.

[66] El-Dammanhoury, H. M., and M. D. Gaintatzopouliu. Self-etching ceramic primer versus hydrofluoric acid etching: Etching efficacy and bonding performance. Journal of Prosthodontic Research, Vol. 62, 2018, pp. 75-83.

[67] Monteiro, J. B., M. G. Oliani, L. F. Guilardi, C. Prochnow, G. K. Rocha Pereira, M. A. Bottino, et al. Fatigue failure load of zirconiareinforced lithium silicate glass ceramic cemented to a dentin analogue: Effect of etching time and hydrofluoric acid concentration. Journal of the Mechanical Behavior of Biomedical Materials, Vol. 77, 2018, pp. 375-382.

[68] Vistas, C. R., C. P. Aguas, and G. N. M. Ferreira. Silanization of glass chips-A factorial approach for optimization. Applied Surface Science, Vol. 286, 2013, pp. 314-318.

[69] Queiroz, J. R. C., P. Benetti, M. Ozcan, L. F. de Oliveira, A. Della Bona, F. E. Takahashi, and M. A. Bottino. Surface characterization of feldspathic ceramic using ATR FT-IR and ellipsometry after various silanization protocols. Dental Materials, Vol. 28, No. 2, Feb. 2012, pp. 189-196.

[70] Chen, J., K. Zhang, Z. Kuang, G. Hu, Q. Song, and Y. Chang. The anisotropic distortional yield surface constitutive model based on the chaboche cyclic plastic model. Materials, Vol. 12, No. 3 , 2019, id. 543.

[71] Nguyen, H. H., S. Wan, K. A. Tieu, H. Zhu, and S. T. Pham. Rendering hydrophilic glass-ceramic enamel surfaces hydrophobic by acid etching and surface silanization for heat transfer appli- 
cations. Surface and Coatings Technology, Vol. 370, 2019, pp. 82-96.

[72] Ferraris, S., A. Nommeots-Nomm, S. Spriano, E. Vernè, and J. Massera. Surface reactivity and silanization ability of borosilicate and Mg-Sr-based bioactive glasses. Applied Surface Science, Vol. 475, 2019, pp. 43-55.

[73] de Figueiredo, V. M. G., P. H. Corazza, L. S. S. Lepesqueur, G. M. Miranda, C. Pagani, R. M. de Melo, and L. F. Valandro. Heat treatment of silanized feldspathic ceramic: Effect on the bond strength to resin after thermocycling. International Journal of Adhesion and Adhesives, Vol. 63, 2015, pp. 96-101.

[74] Caravaca, C., L. Shi, S. Balvay, P. Rivory, E. Laurenceau, Y. Chevolot, D. Hartmann, L. Gremillard, and J. Chevalier. Direct silanization of zirconia for increased biointegration. Acta Biomaterialia, Vol. 46, Dec. 2016, pp. 323-335.

[75] Bisues, M., and V. M. Sglaco. Flash sintering of ceramics. Journal of the European Ceramic Society, Vol. 39, 2019, pp. 115-143.

[76] Aurélio, I. L., C. Prochnow, L. F. Guilardi, G. F. Ramos, M. A. Bottino, and L. G. May. The effect of extended glaze firing on the flexural fatigue strength of hard-machined ceramics. Journal of Prosthetic Dentistry, Vol. 120, No. 5, Nov. 2018, pp. 755-761.

[77] Meng, H., H. Xie, L. Yang, B. Chen, Y. Chen, H. Zhang, and C. Chen. Effects of multiple firings on mechanical properties and resin bonding of lithium disilicate glass-ceramic. Journal of the Mechanical Behavior of Biomedical Materials, Vol. 88, Dec. 2018, pp. 362-369.

[78] Zhang, B., B. Ma, X. Zhang, Q. Zhu, X. Ren, Y. Zhang, X. Qu, J. Yu, and J. Yu. Effects of YSZ and nano-ZrO2 contents on the properties of Ti2448-ZrO2 biomedical composites fabricated by SPS. Cera. Intern., Vol. 44, No. 11, 2018, pp. 13293-13302.

[79] Hallmann, L., P. Ulmer, and M. Kern. Effect of microstructure on the mechanical properties of lithium disilicate glass-ceramics. Journal of the Mechanical Behavior of Biomedical Materials, Vol. 82, Jun. 2018, pp. 355-370.

[80] Belli, R., M. Wendler, M. R. Cicconi, D. de Ligny, A. Petschelt, K. Werbach, et al. Fracture anisotropy in texturized lithium disilicate glass-ceramics. Joural of Non Crystalline Solids, Vol. 481, 2018, pp. 457-469.

[81] Psoritong, S., A. L. Z. Borges, T.-M. G. Chu, et al. Dental Materials, Vol. 29, No. 11, 2013, pp. e281-e290.

[82] Papynov, E. K., A. S. Portnyagin, E. B. Modin, V. Yu. Mayorov, 0. 0. Shichalin, A. P. Golikov, et al. A complex approach to assessing porous structure of structured ceramics obtained by SPS technique. Materials Characterization, Vol. 145, 2018, pp. 294-302.

[83] Schunemann, F. H., M. E. Galarraga-Vinueza, R. Magini, M. Fredel, F. Silva, J. C. M. Souza, Y. Zhang, and B. Henriques. Zirconia surface modifications for implant dentistry. Materials Science and Engineering C, Vol. 98, 2019, pp. 1294-1305.

[84] Poole, S. F., G. K. R. Pereira, E. A. Gomes, A, Gaioto Marques, R. Faria Ribeiro, and E. A. Gomes. Physical properties of conventional and monolithic yttria-zirconia materials after lowtemperature degradation. Ceramics International, Vol. 45, No. 16, 2019, pp. 21038-21043.

[85] Okada, M., H. Taketa, Y. Torii, M. Irie, and T. Matsumoto. Optimal sandblasting conditions for conventional-type yttria-stabilized tetragonal zirconia polycrystals. Dental Materials, Vol. 35, No. 1, Jan. 2019, pp. 169-175.

[86] Biesuz, M., and V. M. Sglavo. Flash sintering of ceramics. Journal of the European Ceramic Society, Vol. 39, No. 2-3, 2019, pp. 115143.
[87] Liu, K., W. Wang, Q. Liu, L. Song, Y. Guo, and F. Ye. Photostriction properties of PLZT $(4 / 52 / 48)$ ceramics sintered by SPS. Ceramics International, Vol. 45, No. 2, 2019, pp. 2097-2102.

[88] Heydarian, A., S. A. Sajjadi, F. Kern, and M. Johnsson. Characteristics evaluation of $\mathrm{SiC} / \mathrm{Si}$ nanocomposites produced by spark plasma sintering. Materials Science and Technology, Vol. 35, No. 10, 2019, pp. 1204-1211.

[89] Pazourková, L., M. Hundáková, P. Peikertová, and G. Simha Martynková. Preparation of calcium-deficient hydroxyapatite particles on vermiculite by precipitation and sonication. J. Austr. Ceram. Soc., Vol. 53, No. 2, 2017, pp. 775-785.

[90] Swain, M. V., V. Mercurio, J. E. Tibballs, and M. Tholey. Thermal induced deflection of a porcelain-zirconia bilayer: Influence of cooling rate. Dental Materials, Vol. 35, No. 4, 2019, pp. 574-584.

[91] Wei, Ch., and L. Gremillard. Surface treatment methods for mitigation of hydrothermal ageing of zirconia. Journal of the European Ceramic Society, Vol. 39, No. 14, 2019, pp. 4322-4329.

[92] Samanta, A., S. Podder, C. K. Ghosh, M. Bhattacharya, J. Ghosh, A. K. Mallik, et al. ROS mediated high anti-bacterial efficacy of strain tolerant layered phase pure nano-calcium hydroxide. Journal of the Mechanical Behavior of Biomedical Materials, Vol. 72, 2017, pp. 110-128.

[93] Ahmed, R. A., and W. A. Aashahrani. Influence of fluoride and/or bovine albumin and some common beverages on electrochemical properties of ionic liquid coated Zirconium for enhancing dental implantology performance. Journal of Molecular Liquids, 279, 2019, 548-560.

[94] Nakonieczny, D. S., M. Basiaga, A. Sambok, M. Antonowicz, Z. K. Paszenda, A. Ziębowicz, et al. Ageing of Zirconia Dedicated to Dental Prostheses for Bruxers Part 2: Influence of Heat Treatment for Surface Morphology, Phase Composition and Mechanical Properties. Reviews on Advanced Materials Science, Vol. 58, No. 1, 2019, pp. 218-225.

[95] Nakonieczny, D. S., A. Sambok, M. Antonowicz, M. Basiaga, Z. K. Paszenda, C. Krawczyk, et al. Ageing of Zirconia Dedicated to Dental Prostheses for Bruxers Part 1: Influence of Accelerating Ageing for Surface Topography and Mechanical Properties. Reviews on Advanced Materials Science, Vol. 58, No. 1, 2019, pp. 189-194.

[96] Nakonieczny, D. S., Z. K. Paszenda, M. Basiaga, T. Radko, S. Drewniak, J. Podwórny, et al. Phase composition and morphology characteristics of ceria-stabilized zirconia powders obtained via sol-gel method with various $\mathrm{pH}$ conditions. Acta of Bioengineering and Biomechanics, Vol. 19, No. 2, 2017, pp. 21-30.

[97] De Barreto Aranha, R. L., M. H. De Abreu, J. M. Serra-Negra, and Renata Castro Martins. Current evidence about relationships among prosthodontic planning and temporomandibular disorders and/or bruxism. Journal of Evidenced Based Dental Practice, Vol. 18, No. 3, 2018, pp. 263-267.

[98] Wang, Y., Q. Yu, M. Cai, F. Zhou, and W. Liu. Halide-free PN ionic liquids surfactants as additives for enhancing tribological performance of water-based liquid. Tribology International, Vol. 128, 2018, pp. 190-196.

[99] Huang, W., M. Wang, H. Wang, N. Ma, and X. Li. The electrodeposition of aluminum on TiB2/A356 composite from ionic liquid as protective coating. Surface and Coatings Technology, Vol. 213, 2012, pp. 264-270.

[100] Binks, F. C., G. Cavalli, M. Henningsen, B. J. Howlin, and I. Hamerton. Investigating the mechanism through which ionic liquids initiate the polymerisation of epoxy resins. Polymer, Vol. 139, 
2018, pp. 163-176.

[101] Binks, F. C., G. Cavalli, M. Henningsen, B. J. Howlin, and I. Hamerton. Examining the effects of storage on the initiation behaviour of ionic liquids towards the cure of epoxy resins. Reactive \& Functional Polymers, Vol. 133, 2018, pp. 9-20.

[102] Jose, J. P., S. K. Malhotra, S. Thomas, K. Joseph, K. Goda, and M. S. Sreekala. Polymer Composites, 1. Wiley, Germany, 2012, pp. 1-16.

[103] Zagho, M. M., E. A. Hussein, and A. A. Elzatahry. Recent Overviews in Functional Polymer Composites for Biomedical Applications. Polymers, Vol. 10, No. 7, Jul. 4, 2018, p. 739.

[104] Denissen, H. W., and K. de Groot. Immediate dental root implants from synthetic dense calcium hydroxylapatite. Journal of Prosthetic Dentistry, Vol. 42, No. 5, Nov. 1979, pp. 551-556.

[105] Thomas, M. V., and D. A. Puleo. Calcium sulfate: Properties and clinical applications. Journal of Biomedical Materials Research. Part B, Applied Biomaterials, Vol. 88, No. 2, Feb. 2009, pp. 597610.

[106] Medvedovski, F. E. Alumina-mullite ceramics for structural applications. Ceramics International, Vol. 32, No. 4, 2006, pp. 369375.

[107] Denry, I., and J. R. Kelly. State of the art of zirconia for dental applications. Dental Materials, Vol. 24, No. 3, Mar. 2008, pp. 299-307.

[108] Manicone, P. F., P. Rossi lommetti, and L. Raffaelli. An overview of zirconia ceramics: Basic properties and clinical applications. Journal of Dentistry, Vol. 35, No. 11, Nov. 2007, pp. 819-826.

[109] Kokubo, T. Bioactive glass ceramics: Properties and applications. Biomaterials, Vol. 12, No. 2, Mar. 1991, pp. 155-163.

[110] Dziadek, M., J. Pawlik, E. Menaszek, E. Stodolak-Zych, and K. Cholewa-Kowalska. Effect of the preparation methods on architecture, crystallinity, hydrolytic degradation, bioactivity, and biocompatibility of $\mathrm{PCL}$ /bioglass composite scaffolds. Journal of Biomedical Materials Research. Part B, Applied Biomaterials, Vol. 103, No. 8, Nov. 2015, pp. 1580-1593.

[111] Vargas, G. E., L. A. Haro Durand, V. Cadena, M. Romero, R. V. Mesones, M. Mačković, S. Spallek, E. Spiecker, A. R. Boccaccini, and A. A. Gorustovich. Effect of nano-sized bioactive glass particles on the angiogenic properties of collagen based composites. Journal of Materials Science. Materials in Medicine, Vol. 24, No. 5, May 2013, pp. 1261-1269.

[112] Tamjid, E., R. Bagheri, M. Vossoughi, and A. Simchi. Effect of particle size on the in vitro bioactivity, hydrophilicity and mechanical properties of bioactive glass-reinforced polycaprolactone composites. Materials Science and Engineering C, Vol. 31, No. 7, 2011, pp. 1526-1533.

[113] Lopes, M. S., A. L. Jardini, and R. M. Filho. Poly (Lactic Acid) Production for Tissue Engineering Applications. Procedia Engineering, Vol. 42, Supplement C, 2012, pp. 1402-1413.

[114] Alizadeh-Osgouei, M., Y. Li, and C. Wen. A comprehensive review of biodegradable synthetic polymer-ceramic composites and their manufacture for biomedical applications. Bioactive Materials, Vol. 4, No. 1, Nov. 27, 2018, pp. 22-36.

[115] Leenslag, J. W., A. J. Pennings, R. R. M. Bos, F. R. Rozema, and G. Boering. Resorbable materials of poly(L-lactide). VI. Plates and screws for internal fracture fixation. Biomaterials, Vol. 8, No. 1 Jan. 1987, pp. 70-73.

[116] Sunita, P. V., and J. Muthu. Polymer ceramic composite materials for orthopedic applications - relevance and need for mechanical match and bone regeneration. Journal of Mechantronics, Vol. 2,
No. 1, 2014, pp. 1-10.

[117] Deng, X., J. Hao, and C. Wang. Preparation and mechanical properties of nanocomposites of poly(D,L-lactide) with Ca-deficient hydroxyapatite nanocrystals. Biomaterials, Vol. 22, No. 21, Nov. 2001, pp. 2867-2873.

[118] Nejati, E., H. Mirzadeh, M. Zandi. Synthesis and characterization of nano-hydroxyapatite rods/poly(l-lactide acid) composite scaffolds for bone tissue engineering. Composites Part A: Applied Science and Manufacturing, Vol. 39, No. 10, 2008, pp. 15891596.

[119] Bonfield, W., M. D. Grynpas, A. E. Tully, J. Bowman, and J. Abram Hydroxyapatite reinforced polyethylene - a mechanically compatible implant material for bone replacement. Biomaterials, Vol. 2, 1981, pp. 185-186.

[120] Boyd, D., M. R. Towler, A. Wren, and O. M. Clarkin. Compari-

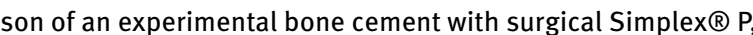
Spineplex $®$ and Cortoss $®$. Journal of Material Science, Vol. 19, 2008, pp. 1745-1752.

[121] Puska, M., J. Korventausta, S. Garoushi, J. Seppälä, P. K. Vallittu, and A. Aho. Preliminary in vitro biocompatibility of injectable calcium ceramic-polymer composite bone cement. Key Engineering Materials Bioceramics, Vol. 396-398, 2009, pp. 273-276.

[122] Jayabalan, M., V. Thomas, and P. K. Sreelatha. Studies on poly(propylene fumarate-co-ethylene glycol) based bone cement. Bio-Medical Materials and Engineering, Vol. 10, No. 2, 2000, pp. 57-71.

[123] Singh, L., V. Kumar, and B. D. Ratner. Generation of porous microcellular $85 / 15$ poly (DL-lactide-co-glycolide) foams for biomedical applications. Biomaterials, Vol. 25, No. 13, Jun. 2004, pp. 2611-2617.

[124] Khan, Y. M., E. K. Cushnie, J. K. Kelleher, and C. T. Laurencin. In situ synthesized ceramic-polymer composites for bone tissue engineering: Bioactivity and degradation studies. Journal of Materials Science, Vol. 42, No. 12, 2007, pp. 4183-4190.

[125] Fteier, V., C. Koplin, and A. Kailer. Influence of pressure-assisted polymerization on the microstructure and strength of polymerinfiltrated ceramics. Journal of Materials Science, Vol. 48, 2013, pp. 3239-3247.

[126] Braem, M., W. Finger, V. E. Van Doren, P. Lambrechts, and G. Vanherle. Mechanical properties and filler fraction of dental composites. Dental Materials, Vol. 5, No. 5, Sep. 1989, pp. 346-348.

[127] Urabe, H., Y. Nomura, K. Shirai, M. Yoshioka, and H. Shintani. Effect of filler content and size to properties of composite resins on microwave curing. Journal of Materials Science. Materials in Medicine, Vol. 10, No. 6, Jun. 1999, pp. 375-378.

[128] Mendes, S. F., C. M. Costa, C. Caparros, V. Sencadas, and S. Lanceros-Méndez. Effect of filler size and concentration on the structure and properties of poly(vinylidene fluoride)/BaTiO3 nanocomposites. Journal of Materials Science, Vol. 47, No. 3, 2012, pp. 1378-1388.

[129] Mao, D., Q. Li, N. Bai, H. Dong, and D. Li. Porous stable poly(lactic acid)/ethyl cellulose/hydroxyapatite composite scaffolds prepared by a combined method for bone regeneration. Carbohydrate Polymers, Vol. 180, Jan. 15, 2018, pp. 104-111.

[130] Schek, R. M., J. M. Taboas, S. J. Hollister, and P. H. Krebsbach. Tissue engineering osteochondral implants for temporomandibular joint repair. Orthodontics \& Craniofacial Research, Vol. 8, No. 4, Nov. 2005, pp. 313-319.

[131] Lundin, J. G., C. L. McGann, G. C. Daniels, B. C. Streifel, and J. H. Wynne. Hemostatic kaolin-polyurethane foam composites for 
multifunctional wound dressing applications. Materials Science and Engineering C, Vol. 79, 2017, pp. 702-709.

[132] Cannillo, V., F. Bondioli, L. Lusvarghi, M. Montorsi, M. Avella, M. E. Errico, et al. Modeling of ceramic particles filled polymermatrix nanocomposites. Composites Science and Technology, Vol. 66, No. 7-8, 2006, pp. 1030-1037.

[133] Braem, M., W. Finger, V. E. Van Doren, P. Lambrechts, and G. Vanherle. Mechanical properties and filler fraction of dental composites. Dental Materials, Vol. 5, 1989, pp. 346-349.

[134] Urabe, H., Y. Nomura, K. Shirai, M. Yoshioka, and H. Shintani. Effect of filler content and size to properties of composite resins on microwave curing. Journal of Material Science, Vol. 10, No. 6, 1999, pp. 375-378.

[135] Mendes, S. F., C. M. Costa, C. Caparros, V. Sencadas, and S. Lanceros-Méndez. Effect of filler size and concentration on the structure and properties of poly(vinylidene fluoride)/BaTiO3 nanocomposites. Journal of Materials Science, Vol. 47, No. 3, 2012, pp. 1378-1388.
[136] Halvorson, R. H., R. L. Erickson, and C. L. Davidson. The effect of filler and silane content on conversion of resin-based composite. Dental Materials, Vol. 19, No. 4, 2003, pp. 327-333.

[137] Coldea, A., M. V. Swain, and N. Thiel. Mechanical properties of polymer-infiltrated-ceramic-network materials. Dental Materials, Vol. 29, No. 4, 2013, pp. 419-426.

[138] Li, S., Y. Zhao, J. F. Zhang, C. Xie, and X. Zhao. Machinability of poly(methyl methacrylate) infiltrated zirconia hybrid composites. Materials Letters, Vol. 131, 2014, pp. 347-349.

[139] Li, S. B., Y. M. Zhao, J. F. Zhang, C. Xie, D. M. Li, L. H. Tang, et al. Mechanical properties and microstructure of PMMA-ZrO2 nanocomposites for dental CAD/CAM. Advanced Materials Research, 65 Vol. 785-786, 2013, pp. 533-536.

[140] Xie, C., J. F. Zhang, S. Li, O. Hea. and Dent. Stud, Vol. 1, 2018, pp. 1-11.

[141] Xie, C., J. F. Zhang, and S. Li. Polymer infiltrated ceramic hybrid composites as dental materials. Oral Health and Dental Studies, Vol. 1, No. 1-2, 2018, pp. 1-11. 